\author{
Marzena Półka ${ }^{a)^{*}}$, Robert Piec ${ }^{a)}$, Dariusz Olcen ${ }^{a)}$ \\ a) The Main School of the Fire Service, Safety Engineering and Civil Protection Department / Szkoła Główna Służby Pożarniczej, \\ Wydział Inżynierii Bezpieczeństwa i Ochrony Ludności \\ *Corresponding author / Autor korespondencyjny: mpolka@sgsp.edu.pl
}

\title{
Analysis of Fire and Explosion Properties of LNG
}

\section{Analiza właściwości pożarowych i wybuchowych LNG}

\begin{abstract}
Aim: The aim of this article is to analyse fire and explosion properties of LNG along with the identification of hazards that may arise during emergency incidents involving it. The article is based on an analysis of the available literature and a full-scale experimental study involving a 200-liter LNG tank leading to a jet fire.

Introduction: Safe use and proper transport of flammable and harmful substances, together with the analysis of the effects of threats, enable the reduction of the number of accidents and provide possible conditions for the evacuation of people and property in a hazard zone. The compilation and systematization of knowledge on the safe use of the environmentally friendly LNG fuel will allow for an increase in the scope of its use. It is consistent with the state's sustainable development policy consisting in identifying threats or adjusting technical solutions that minimize losses in transport or industry. Methodology: There are many legal acts in the world regarding safe storage and transport of LNG. One of the most important is Directive 2012/18/EC known as "Seveso III". This document contains requirements for the prevention of major accidents involving hazardous substances - including LNG and ways to reduce their negative effects on human health and the environment. Relevant requirements have also been specified in standards, tests, articles and other international acts, including in the European agreement on the international carriage of dangerous goods by road (the so-called ADR Agreement). The article compares flammable and explosive parameters of LNG. Possible scenarios occurring during the release and ignition of the LNG vapour cloud have been shown. The change of pressure of LNG vapour in the 200 I tank as a function of its heating time in the burning spill of a mixture of gasoline and diesel fuel is presented. In such a thermal exposure, a jet fire with a flame length of up to 5 meters was obtained.

Conclusions: The proper use of flammable gases should be a priority in ensuring fire and explosion safety in facilities, during transport, etc. Hence, recognizing the threats and comparing them, or matching technical solutions that minimize the effects of LNG failures will allow active inclusion of knowledge in this field in the process of protection against fire and explosion. In case of LNG storage, attention should be paid to the types of materials in the immediate vicinity of this liquefied gas in order to have sufficient mechanical properties at the lowest liquefied gas temperature. Keywords: LNG, fire safety, process safety
\end{abstract}

Article type: review article

Received: 05.11.2021; Reviewed: 24.11.2021; Accepted: 24.11.2021;

Authors' ORCID IDs: M. Półka - 0000-0002-2280-8137; R. Piec - 0000-0002-5234-5639; Dariusz Olcen - 0000-0003-1384-1215;

The authors contributed the equally to this article;

Please cite as: SFT Vol. 58 Issue 2, 2021, pp. 58-73, https://doi.org/10.12845/sft.58.2.2021.4;

This is an open access article under the CC BY-SA 4.0 license (https://creativecommons.org/licenses/by-sa/4.0/).

\section{ABSTRAKT}

Cel: Celem artykułu jest analiza właściwości pożarowych i wybuchowych LNG wraz z określeniem zagrożeń, które mogą pojawić się podczas zdarzeń awaryjnych z jego udziałem. Artykuł opiera się na analizie dostępnej literatury oraz badaniu eksperymentalnym w pełnej skali z udziałem zbiornika LNG o pojemności 200 litrów doprowadzającego do powstania pożaru strumieniowego (ang. jet fire)

Wprowadzenie: Bezpieczne stosowanie oraz właściwy transport substancji palnych i szkodliwych wraz z analizą skutków zagrożeń umożliwiają zmniejszenie liczby awarii i dostarczają możliwe warunki do ewakuacji osób oraz mienia znajdujących się w strefie zagrożenia. Zestawienie i usystematyzowanie wiedzy dotyczącej bezpiecznego stosowania paliwa LNG przyjaznego dla środowiska pozwoli na zwiększenie zakresu jego wykorzystania. Jest to spójne z polityką zrównoważonego rozwoju państwa polegającą na identyfikacji zagrożeń czy dopasowaniu rozwiązań technicznych minimalizujących straty w transporcie lub przemyśle.

Metodologia: Na świecie istnieje wiele aktów prawnych dotyczących bezpiecznego magazynowania, składowania oraz transportu LNG. Jednym z najważniejszych jest dyrektywa 2012/18/WE znana jako „Seveso III". Dokument ten zawiera wymagania dotyczące zapobiegania poważnym awariom z udziałem substancji niebezpiecznych - w tym LNG - oraz sposoby zmniejszenia ich negatywnych skutków dla zdrowia ludzkiego i środowiska. Istotne 
wymagania zostały określone także w normach, badaniach, artykułach i innych aktach międzynarodowych, m.in. w umowie europejskiej dotyczącej międzynarodowego przewozu drogowego towarów niebezpiecznych (tzw. Umowa ADR). W artykule dokonano zestawienia parametrów palnych i wybuchowych LNG. Ukazano możliwe scenariusze zachodzące podczas uwolnienia i zapłonu chmury par LNG. Przestawiono zmianę ciśnienia par LNG w zbiorniku o pojemności 200 I w funkcji czasu jego ogrzewania w palącym się rozlewisku mieszaniny benzyny z olejem napędowym. W takiej ekspozycji cieplnej otrzymano pożar strumieniowy o długości płomienia maksymalnie 5 metrów.

Wnioski: Właściwe stosowania gazów palnych powinno być priorytetem w zapewnieniu bezpieczeństwa pożarowego i wybuchowego w obiektach, transporcie itp. Stąd też poznanie zagrożeń i ich zestawienie, czy dopasowanie rozwiązań technicznych minimalizujących skutki awarii z LNG pozwoli na aktywne włączenie wiedzy z tego zakresu w proces zabezpieczenia przed pożarem i wybuchem. W przypadku magazynowania LNG należy zwrócić uwagę na rodzaje materiałów znajdujących się w bezpośrednim otoczeniu z tym gazem skroplonym, aby posiadały wystarczające właściwości mechaniczne w najniższej temperaturze skroplonego gazu.

Słowa kluczowe: LNG, bezpieczeństwo pożarowe, bezpieczeństwo procesowe

Typ artykułu: artykuł przeglądowy

Przyjęty: 05.11.2021; Zrecenzowany: 24.11.2021; Zaakceptowany: 24.11.2021;

Identyfikatory ORCID autorów: M. Półka - 0000-0002-2280-8137; R. Piec - 0000-0002-5234-5639; Dariusz Olcen - 0000-0003-1384-1215;

Autorzy wnieśli równy wkład merytoryczny w powstanie artykułu;

Proszę cytować: SFT Vol. 58 Issue 2, 2021, pp. 58-73, https://doi.org/10.12845/sft.58.2.2021.4;

Artykuł udostępniany na licencji CC BY-SA 4.0 (https://creativecommons.org/licenses/by-sa/4.0/)

\section{Introduction}

Constant human need to maintain an adequate standard of living generates a greater or lesser degree of demand for energy. Saving, optimal use and the search for renewable energy sources should be the subject of action in order to ensure continuity of energy supply. Certainly, the demand for energy and sources that can provide it, along with its safe use, must be consistent with the country's sustainable development policy [1]. The analysis of the safe use of flammable gases in the context of sustainable development, consisting in learning about the risks or adjusting technical solutions that minimize losses in transport or industry, allows to increase the level of safety of all rescuers and the people in the vicinity of flammable gases. Currently, the concept of sustainable development is increasingly entering the mainstream discussion on socio-economic development, becoming a horizontal principle reflected in the development policies of many countries, including fire safety. According to the U.S. Energy Information Agency [2], energy consumption by 2040 will increase by $28 \%$ of the previous level. All over the world, intensive efforts are made to develop renewable energy sources and nuclear energy. The production of this type of energy is prospective, but it is forecast that most of the energy generated in the world will be dominated by the use of crude oil and natural gas [2]. Among the various methods of energy production, the use of LNG (liquefied natural gas) as an energy source is considered to be more environmentally friendly than coal-fired or nuclear energy [3]. Power plants for regasification of liquefied natural gas, e.g. integrated with liquid air energy storage (LAES), due to their flexibility, seem to be a favourable technological solution (they adjust the electricity demand profile to the increased operating profits from energy arbitrage) [4]. The construction of the LNG terminal in Poland in Świnoujście in 2016 made it possible to receive liquefied natural gas by sea from virtually any direction in the world, which contributed to the

\section{Wstęp}

Ciągła potrzeba człowieka dotycząca utrzymania odpowiedniego poziomu życia generuje w mniejszym lub większym stopniu popyt na energię. Oszczędzanie, optymalne wykorzystanie i poszukiwanie odnawialnych źródeł energii powinno być przedmiotem działania w celu zapewnienia ciągłości dostaw energii. $\mathrm{Na}$ pewno zapotrzebowanie na energię i źródła, które mogą ją zapewnić wraz z bezpiecznym jej stosowaniem, muszą być spójne z polityką zrównoważonego rozwoju państwa [1]. Analiza bezpiecznego stosowania gazów palnych w kontekście zrównoważonego rozwoju, polegająca na poznaniu zagrożeń czy dopasowaniu rozwiązań technicznych minimalizujących straty $w$ transporcie lub przemyśle, pozwala na zwiększenie poziomu bezpieczeństwa wszystkich ratowników i osób przebywających w otoczeniu gazów palnych. Obecnie koncepcja zrównoważonego rozwoju coraz częściej wchodzi do głównego nurtu dyskusji nad rozwojem społeczno-gospodarczym, stając się zasadą horyzontalną, odzwierciedlaną w polityce rozwoju wielu państw, w tym również bezpieczeństwie pożarowym. Jak podaje U.S. Energy Information Agency [2], zużycie energii do 2040 r. wzrośnie o $28 \%$ dotychczasowego poziomu. Na całym świecie podejmowane są intensywne działania na rzecz rozwoju źródeł energii odnawialnej i energetyki jądrowej. Wytwarzanie tego rodzaju energii jest perspektywiczne, niemniej prognozuje się, że większość wytwarzanej energii na świecie będzie jednak zdominowana wykorzystaniem ropy naftowej i gazu ziemnego [2]. Wśród różnych metod wytwarzania energii, wykorzystanie LNG (ang. liquefied natural gas) jako źródła energii jest uważane za bardziej przyjazne dla środowiska niż opalanie węglem czy energia jądrowa [3]. Elektrownie do regazyfikacji skroplonego gazu ziemnego np. zintegrowane z magazynowaniem energii ciekłego powietrza (ang. liquid air energy storage, LAES), ze względu na swą elastyczność wydają się być korzystnym rozwiązaniem technologicznym (dopasowują profil zapotrzebowania na energię elektryczną do zwiększonych zysków operacyjnych 
diversification of gas supply sources and strengthened Poland's energy security. Distribution of the natural gas via a gas pipeline network is problematic due to the distance between the existing deposits and the potential recipients, as well as the significant costs and time of the investment. As a result, the LNG transport market is becoming more and more popular, as it enables the supply of natural gas to places where network connections are not available. The benefits of this solution mean that there are more and more supporters of the development of the infrastructure that allows for road and rail transport of natural gas processed into a liquid form. In land transport, liquefied natural gas is delivered by road and rail tankers. The possibilities offered by road transport include, above all, speed, availability and flexibility of the deliveries. Unfortunately, also during transport dangerous incidents can occur with LNG. An example of an incident involving LPG was recorded in 2011 in the province of Murcia in Spain - the driver lost control of the vehicle, drove off the road and got stuck in a ditch between the embankment and the roadside. Probably as a result of a fuel leak and the simultaneous presence of an effective energy stimulus, the tanker burst into flames, and then exploded [5].

One of the likely events involving LNG, which can cause high losses, is the boiling liquid expanding vapour explosion (BLEVE). In 1940-2005, more than 1,000 people died as a result of more than 80 BLEVE incidents of flammable substances, more than 10,000 people were injured, and property losses amounted to billions of dollars [6]. Additionally, during the BLEVE explosion, toxic compounds such as chlorine and phosgene may be released, and the infrastructure surrounding the explosion site is destroyed. Hence, getting to know the chemical properties of LNG and the analysis of the possible threats is necessary to predict and limit the effects of its release.

\section{Physicochemical properties of LNG}

One of the key energy resources used in the household and industry is natural gas [7-9]. In the industry,this gas is used in two forms - in a liquefied form as LNG and in a compressed form as CNG (compressed natural gas). Natural gas consists of over $90 \%$ methane, which is the simplest hydrocarbon belonging to the alkanes. Methane is produced naturally under the conditions of anaerobic decomposition of organic matter, and such processes are favoured by wet lands, e.g. marshes (hence it is called "mud" gas) or it can be produced synthetically [10]. The world's largest deposits of the natural gas are located primarily in Russia, the Middle East, the United States, Canada and Mexico. In Western European countries, the largest deposits are found in the Netherlands and under the bottom of the British and Norwegian sectors of the North Sea. Natural gas in room conditions (i.e. approx. $23^{\circ} \mathrm{C}$ and $1024 \mathrm{hPa}$ ) is a colourless and odourless z arbitrażu energii elektrycznej) [4]. Powstanie terminalu LNG w Polsce w Świnoujściu w 2016 r. pozwoliło na odbieranie skroplonego gazu ziemnego drogą morską praktycznie z dowolnego kierunku na świecie, co przyczyniło się do otworzenia drogi do dywersyfikacji źródeł dostaw gazu i wzmocniło bezpieczeństwo energetyczne Polski. Dystrybucja gazu ziemnego za pomocą sieci gazociągowej jest problematyczna ze względu na odległość pomiędzy istniejącymi złożami a potencjalnymi odbiorcami oraz znaczne koszty i czas wykonania inwestycji. W związku z tym coraz większym zainteresowaniem cieszy się rynek transportu LNG pozwalający na dostarczanie gazu ziemnego tam, gdzie nie są dostępne połączenia sieciowe. Korzyści płynące $z$ tego rozwiązania powodują, że stale przybywa zwolenników rozwoju infrastruktury pozwalającej na transport drogowy i kolejowy gazu ziemnego przetworzonego do postaci ciekłej. W transporcie lądowym skroplony gaz ziemny jest dostarczany przy pomocy autocystern i cystern kolejowych. Możliwości, jakie daje transport samochodowy, to przede wszystkim szybkość, dostępność i elastyczność dostaw. Niestety również podczas transportu LNG może dojść do zdarzeń niebezpiecznych. Przykładowe zdarzenie z udziałem LPG zanotowano w 2011 roku w prowincji Murcia w Hiszpanii - kierowca stracił kontrolę nad pojazdem, zjechał $z$ drogi i zaklinował się $w$ rowie między nasypem a poboczem drogi. Prawdopodobnie w skutek wycieku paliwa oraz jednoczesnej obecności efektywnego bodźca energetycznego, cysterna stanęła w płomieniach, a zaraz potem nastąpił jej wybuch [5].

Jednym z prawdopodobnych zdarzeń z udziałem LNG, które może powodować duże straty, jest wybuch ekspandującej pary z wrzącej cieczy (ang. boiling liquid expanding vapour explosion, BLEVE). W latach 1940-2005 w skutek powstania ponad $80 \mathrm{zda}-$ rzeń BLEVE substancji palnych zginęło ponad 1000 ludzi, poszkodowanych zostało ponad 10000 osób, a straty mienia wynosiły miliardy dolarów [6]. Dodatkowo podczas wybuchu BLEVE może dochodzić do uwalniania toksycznych związków, takich jak chlor i fosgen, zniszczeniu ulega infrastruktura w otoczeniu miejsca powstania wybuchu. Stąd też poznanie właściwości chemicznych LNG, analiza możliwych zagrożeń jest niezbędna do przewidywania i ograniczania skutków jego uwolnienia.

\section{Właściwości fizykochemiczne LNG}

Jednym z kluczowych surowców energii wykorzystywanym w gospodarstwie domowym i przemyśle jest gaz ziemny [7-9]. $W$ przemyśle gaz ten stosuje się $w$ dwóch postaciach - $w$ formie skroplonej jako LNG oraz w postaci sprężonej jako CNG (ang. compressed natural gas). Gaz ziemny składa się w ponad $90 \%$ z metanu czyli najprostszego węglowodoru należącego do alkanów. Metan powstaje naturalnie w warunkach beztlenowego rozkładu materii organicznej, a takim procesom sprzyjają tereny podmokłe np. mokradła (stąd nazywany jest gazem „błotnym”) lub może być wytwarzany syntetycznie [10]. Największe na świecie złoża gazu ziemnego znajdują się przede wszystkim w Rosji, krajach Bliskiego Wschodu, Stanach Zjednoczonych, Kanadzie, Meksyku. W krajach Europy Zachodniej największe złoża występują w Holandii oraz pod dnem brytyjskiego i norweskiego sektora Morza Północnego. Gaz ziemny w warunkach pokojowych (tj. ok. $23^{\circ} \mathrm{C} \mathrm{i} 1024 \mathrm{hPa}$ ) jest 
substance which, after cleaning and meeting the quality requirements, is liquefied at a temperature of approx. $-162^{\circ} \mathrm{C}$ (the boiling point of LNG depends on its composition and amounts to from $-166^{\circ} \mathrm{C}$ to $-157^{\circ} \mathrm{C}$ ) at normal atmospheric pressure [9-10]. This form of natural gas reduces its volume and facilitates transport and storage in vacuum-insulated tanks (i.e. tanks on LNG carriers, on LNG-powered ships, in permanent storage tanks and cryogenic tanks). Due to its very low temperature, LNG can cause both cracks in the materials that make up the walls of the tank and the ship's structure, as well as cause frostbite in people who come into contact with it. Hence, LNG tanks or fittings must be made of special materials resistant to cryogenic liquids and resistant to low temperatures [11]. LNG leaks can cause water to freeze in the air, creating a white fog. Liquefied natural gas is non-corrosive. The absolute density of LNG in liquid form at a temperature of about $-160^{\circ} \mathrm{C}$, depending on its chemical composition, ranges from $430 \mathrm{~kg} / \mathrm{m}^{3}$ to $470 \mathrm{~kg} / \mathrm{m}^{3}$, and under extreme conditions it can even reach $520 \mathrm{~kg} / \mathrm{m}^{3}$ [9-11]. Hence, LNG spilled on water, the density of which is about $1000 \mathrm{~kg} / \mathrm{m}^{3}$, floats on its surface as a lighter one. LNG - like methane - does not dissolve in water. Liquefied natural gas has a volume approx. 600 times smaller than in the gaseous state, which means that after regasification, $100 \mathrm{~m}^{3}$ of LNG produces $60,000 \mathrm{~m}^{3}$ of natural gas $[1,9]$. Hence, with such efficiency of natural gas, an undesirable event or exposure of fittings to low temperature in LNG leaks may be a factor initiating a fire or explosion, damage to infrastructure and the environment, cause damage to human health or even pose a threat to their lives. The event in the form of oxygen displacement from a given volume (e.g. room) and suffocation of people in it should also be considered. The liquid form of natural gas significantly facilitates its storage and transport, especially by sea. LNG is a liquefied mixture of gaseous hydrocarbons, mainly methane $87-99 \% \mathrm{~mol}$, ethane $0.1-5.5 \% \mathrm{~mol}$, propane $0-4 \% \mathrm{~mol}$, butane $0-2.5 \% \mathrm{~mol}$, nitrogen $0.02-1 \% \mathrm{~mol}$ and traces of sulphur (less than 4 ppmv) and $\mathrm{CO}_{2}$ (50 ppmv) [12]. LNG is a fuel purified from moisture, carbon dioxide, nitrogen and heavier hydrocarbons, and at the same time a non-conductive liquid. Methane and nitrogen are the first components to be released from an LNG leak. The share of hydrocarbons in the mixture remaining after evaporation of these essential components leads to changes in the composition of LNG. In particular, they can be recorded for a batch of raw material originating from different places of its extraction. Non-adiabatic storage of LNG in tanks causes the liquid to evaporate in them, which also changes the composition of the fuel. Sensors based on the measurement of the dielectric constant of LNG enable accurate measurement of the filling level of the tank, especially in vehicles powered by this fuel, as they take into account the splashing of the liquid level caused by the shocks of the LNG vehicle. Yue Fu et al. [13] describes the use of these sensors for the precise filling of car tanks with liquefied natural gas. bezbarwną i bezwonną substancją, która po oczyszczeniu i spełnieniu wymagań jakościowych zostaje skroplona w temperaturze ok. $-162^{\circ} \mathrm{C}$ (temperatura wrzenia LNG zależy od jego składu i wynosi od $-166^{\circ} \mathrm{C}$ do $-157^{\circ} \mathrm{C}$ ) przy normalnym ciśnieniu atmosferycznym [9-10]. Taka forma gazu ziemnego zmniejsza jego objętość oraz ułatwia transport i przechowywanie w zbiornikach izolowanych próżnią (tj. zbiornikach na gazowcach LNG, na statkach zasilanych LNG, w stałych zbiornikach magazynowych i cysternach kriogenicznych). Ze względu na swoją bardzo niską temperaturę LNG może powodować zarówno pęknięcia materiałów, z których zbudowane są ściany zbiornika i konstrukcji statku, jak również spowodować odmrożenia u osób mających z nim kontakt. Stąd też zbiorniki czy armatura z LNG muszą być wykonane ze specjalnych materiałów wytrzymałych na ciecze kriogeniczne, które są odporne na niskie temperatury [11]. Wycieki LNG mogą powodować zamarzanie wody w powietrzu, tworząc białą mgłę. Skroplony gaz ziemny nie jest żrący i nie ma własności korodujących. Gęstość bezwzględna LNG w postaci ciekłej w temperaturze ok. $-160^{\circ} \mathrm{C}$, w zależności od jego składu chemicznego, wynosi od $430 \mathrm{~kg} / \mathrm{m}^{3}$ do $470 \mathrm{~kg} / \mathrm{m}^{3}$, a w skrajnych warunkach osiąga nawet wartość do $520 \mathrm{~kg} / \mathrm{m}^{3}$ [9-11]. Stąd też LNG rozlany na wodzie, której gęstość wynosi ok. $1000 \mathrm{~kg} / \mathrm{m}^{3}$, jako lżejszy unosi się na jej powierzchni. LNG - tak jak i metan - nie rozpuszcza się w wodzie. Skroplony gaz ziemny ma objętość ok. 600 razy mniejszą niż w stanie gazowym, co oznacza, że po regazyfikacji ze $100 \mathrm{~m}^{3}$ LNG otrzymuje się $60000 \mathrm{~m}^{3}$ gazu ziemnego [1, 9]. Stąd przy takiej wydajności gazowego gazu ziemnego, niepożądane zdarzenie czy też ekspozycja armatury na niską temperaturę przy wyciekach LNG, może być czynnikiem inicjującym pożar lub wybuch, zniszczenia w infrastrukturze i środowisku, powodować uszczerbek na zdrowiu ludzi lub wręcz stanowić zagrożenie dla ich życia. Należy również rozpatrzyć zdarzenie w postaci wyparcia tlenu z danej objętości (np. pomieszczenia) i uduszenie osób w nim przebywającym. Postać ciekła gazu ziemnego znacznie ułatwia jego magazynowanie i transport, zwłaszcza transport drogą morską. LNG to skroplona mieszanina gazowych węglowodorów, głównie metanu $87-99 \% \mathrm{~mol}$, etanu $0,1-5,5 \% \mathrm{~mol}$, propanu $0-4 \%$ mol, butanu $0-2,5 \% \mathrm{~mol}$, azotu $0,02-1 \mathrm{~mol} \%$ i śladowych ilości siarki (mniej niż 4 ppmv) oraz $\mathrm{CO}_{2}$ (50 ppmv) [12]. LNG jest paliwem oczyszczonym z wilgoci, dwutlenku węgla, azotu i cięższych węglowodorów i jednocześnie cieczą nieprzewodzącą. Metan i azot są pierwszymi składnikami, które uwalniają się z miejsca wycieku LNG. Udział węglowodorów w pozostałej po odparowaniu tych zasadniczych składników mieszaninie prowadzi do zmian w składzie LNG. W szczególności można je zanotować dla partii surowca pochodzącego z różnych miejsc jego wydobywania. Nieadiabatyczne składowanie LNG w zbiornikach powoduje, że ciecz w nich odparowuje, co również prowadzi do zmiany składu paliwa. Czujniki oparte na pomiarze stałej dielektrycznej LNG umożliwiają dokładny pomiar poziomu napełnienia zbiornika, zwłaszcza w pojazdach napędzanym tym paliwem, gdyż uwzględniają rozchlapywanie się poziomu cieczy spowodowane wstrząsami pojazdu LNG. W publikacji Yue Fu i in. [13] opisano zastosowanie tych czujników do procesu precyzyjnego napełnienia zbiorników samochodowych ze skroplonym gazem ziemnym. 


\section{Fire and explosion hazards of LNG}

Accidents involving LPG take various forms and depend on the conditions of gas operation, storage, and the type of event. The combustion of methane gas, or when released from the liquid phase, is related to the type of emission source, the application of an effective ignition source within its emission, and the time it takes to form a fuel-air cloud. The density of gaseous methane at low temperature, close to its condensation $\left(-160^{\circ} \mathrm{C}\right)$, is approx. $1.751 \mathrm{~kg} / \mathrm{m}^{3}$, so its absolute density is higher than that of air [9]. Hence, when it is released, LNG initially has a temperature close to its condensation temperature and accumulates just above the ground or above the water surface and evaporates using energy from the environment. At this stage, after evaporation, LNG becomes a heavy gas, and its heating to approx. $-123^{\circ} \mathrm{C}$ causes the LNG vapour to become gas with a density similar to air. Then, as the temperature rises to a value of about $-110^{\circ} \mathrm{C}\left(-113^{\circ} \mathrm{C}\right.$ for methane), it becomes lighter than air and mixes easily with it. The initial violent evaporation is continued until the evaporation rate reaches a constant value depending mainly on the thermal properties of the substrate into which LNG is released and the heat obtained from the emission environment - most often from the air. The substrate heats LNG, causing it to evaporate due to heat conduction from the surface, convection from the surrounding air and its humidity [14-17]. Water from air humidity is a latent energy store and supports the process of LNG evaporation. When LNG vapours are mixed with air, the latter is cooled and water from its moisture condenses as a result of the heat released from the phase change of water. If LNG leaks from pressure equipment or pipelines, it will be streamed into the atmosphere. This process is related to the intense physical mixing of LNG with air. At the initial stage of mixing, particles of liquid natural gas in the form of aerosols can be identified in the released cloud of the mixture, which will then gradually evaporate as a result of mixing with air. Ignition of the methane-air mixture formed as a result of LNG release occurs when an appropriate stimulus appears in the range of methane concentration in the air between the lower and upper explosion limits (LEL and UEL) [18]. The explosion limits of methane, like that of other flammable gases, are not constant and depend on pressure and temperature. The presence of inert components affects the ignition of a flammable natural gas mixture. As their concentration increases, the ignition conditions deteriorate and the GGW value drops significantly. Based on the research [16-22], it was found that the LEL of methane is $4.6 \pm 0.3 \%$, and the UEL of methane $-15.8 \pm 0.4 \%$, when methane is ignited in the air at a temperature of $20^{\circ} \mathrm{C}$ and $100 \mathrm{kPa}$ (relates to ambient temperature and pressure), while in oxygen they are 5.1-61.0 vol.\% [19-22]. When the released LNG cloud, spreading in the air just above ground level, finds an effective source of ignition on its way, it can cause an unconfined vapour cloud explosion (UVCE), i.e. an explosion of a vapour cloud in an unlimited space. The concentration of the natural gas in the cloud of released LNG varies - initially highest in the centre of the cloud and right on the ground, up to a very small one at the edge of the cloud. The maximum concentration of the natural

\section{Zagrożenia pożarowo-wybuchowe LNG}

Awarie $z$ udziałem LPG mają różną postać i zależą od warunków eksploatacji gazu, przechowywania, rodzaju zdarzenia. Spalanie metanu w postaci gazowej lub podczas uwalniania go $z$ fazy ciekłej związane jest z rodzajem źródła emisji, przyłożeniem w obrębie jego emisji efektywnego źródła zapłonu i czasem utworzenia obłoku paliwo-powietrze. Gęstość gazowego metanu w niskiej temperaturze, bliskiej skropleniu $\left(-160^{\circ} \mathrm{C}\right)$, wynosi ok. $1,751 \mathrm{~kg} / \mathrm{m}^{3}$, a więc jego gęstość bezwzględna jest większa od gęstości powietrza [9]. Stąd też podczas jego uwolnienia LNG początkowo ma temperaturę zbliżoną do temperatury skroplenia i gromadzi się tuż nad powierzchnią gruntu lub nad powierzchnią wody i odparowuje, wykorzystując energię z otoczenia. Na tym etapie LNG po odparowaniu staje się ciężkim gazem, a jego ogrzanie do temp. ok. $-123^{\circ} \mathrm{C}$ powoduje, że para LNG stanie się gazem o gęstości zbliżonej do powietrza. Następnie wraz ze wzrostem temperatury do wartości ok. $-110^{\circ} \mathrm{C}\left(-113^{\circ} \mathrm{C}\right.$ dla metanu) staje się Iżejszy od powietrza i łatwo się z nim miesza. Początkowo występujące gwałtowne odparowanie jest kontynuowane aż do momentu, gdy szybkość parowania osiągnie stałą wartość zależną głównie od właściwości cieplnych podłoża, na które LNG jest uwalniany oraz ciepła uzyskanego z otoczenia emisji - najczęściej z powietrza. Podłoże ogrzewa LNG, powodując jego odparowanie w skutek przewodzenia ciepła z powierzchni, konwekcję z otaczającego powietrza i jego wilgotności [14-17]. Woda z wilgoci powietrza stanowi magazyn energii utajonej i wspomaga proces odparowania LNG. Podczas mieszania par LNG z powietrzem, to ostatnie jest schładzane i woda $\mathrm{z}$ jego wilgoci ulega skraplaniu jako wynik uwalnianego ciepła z przemiany fazowej wody. Jeśli nastąpi wyciek LNG z urządzeń ciśnieniowych lub rurociągów, będzie się on uwalniał strumieniowo do atmosfery. Proces ten związany jest z intensywnym, fizycznym mieszaniem się LNG z powietrzem. W początkowej fazie mieszania, w uwolnionej chmurze mieszaniny można zidentyfikować cząsteczki ciekłego gazu ziemnego w postaci aerozolu, które następnie - w wyniku procesu mieszania z powietrzem - stopniowo będą odparowywać. Zapłon mieszaniny metanowo-powietrznej utworzonej w wyniku uwolnienia LNG następuje w przypadku, kiedy pojawi się odpowiedni bodziec $w$ zakresie stężenia metanu w powietrzu między dolną i górną granicą wybuchowości (DGW i GGW) [18]. Granice wybuchowości metanu, tak jak i innych gazów palnych, nie są stałe i zależą od ciśnienia oraz temperatury. Na zapłon mieszaniny palnej gazu ziemnego ma wpływ obecność składników obojętnych. Wraz ze wzrostem ich stężenia pogarszają się warunki zapłonu i znacznie obniża się wartość GGW. Na podstawie badań [16-22] stwierdzono, że DGW metanu wynosi $4,6 \pm 0,3 \%$, a GGW metanu $-15,8 \pm 0,4 \%$, gdy metan jest zapalany w powietrzu w temperaturze $20^{\circ} \mathrm{C}$ i $100 \mathrm{kPa}$ (odnosi się do temperatury i ciśnienia otoczenia), natomiast w tlenie wynoszą 5,1-61,0\% obj. [19-22]. Gdy uwolniona chmura LNG, rozprzestrzeniając się w powietrzu tuż nad poziomem gruntu, znajdzie na swej drodze efektywne źródło zapłonu, może spowodować wybuch typu UVCE (ang. unconfined vapor cloud explosion), czyli wybuch chmury par w przestrzeni nieograniczonej. Stężenie gazu ziemnego w chmurze uwolnionego LNG jest różne - początkowo największe w środku chmury i tuż 
gas in the cloud depends mainly on the total volume of air mixed with the gas and the mixing speed. This, in turn, depends on the Pasquill stability class and the degree of turbulence during the mixing process. The size of the formed natural gas cloud depends primarily on the mass of the released LNG, its dispersion time and weather conditions. At the beginning of the LNG dispersion, the greater part of the cloud volume will contain a gas concentration higher than the UEL. However, on the periphery of the cloud, flammable areas of the mixture may form, i.e. the gas concentration will be between the LEL and the UEL. On this basis, it can be concluded that already in the initial stage of an LPG leak, the created gas-air mixture will pose a risk of explosion. At the moment of evaporation of the entire amount of LNG, the gas concentration in the cloud will gradually decrease, even below the LEL value, so the mixture will not pose a risk of explosion [20]. The maximum explosion pressure occurs at a stoichiometric concentration of methane of $\sim 9.5 \%$ [22]. In the released cloud of LNG in open space, the natural gas burns relatively slowly, creating relatively small overpressures of less than $5^{\star} 103 \mathrm{~Pa}$ [22]. Higher values of overpressure resulting from the explosion of the LNG cloud appear in areas where turbulence of the resulting flame may occur, i.e. in areas with a high degree of densification of building and process structures or in spaces limited by obstacles. The value of the maximum pressure and UEL of a methane explosion also increases at an increased initial pressure [18]. The maximum explosion pressure decreases with the increase of the initial temperature of the combustible mixture, because at an elevated temperature the reaction rate of methane combustion is higher, but the total mass of the combustible gas in the combustible mixture with air is lower than at lower temperatures providing the initial pressure. The temperature of a methane explosion in an open space can be as high as $1,875^{\circ} \mathrm{C}$, reaching even $2,650^{\circ} \mathrm{C}$ in a confined space. The ignition temperature of $L P G$ is $-188^{\circ} \mathrm{C}$, auto-ignition $537^{\circ} \mathrm{C}$, and the minimum ignition energy is about $0.25 \mathrm{~mJ}$ [21-22]. Computational fluid dynamics (CFD) allows modelling the process of mixing LNG vapours and air, taking into account the thermodynamic properties of each component depending on the temperature and fluid dynamics. The CFD technique allows to take into account the characteristics of the terrain where the gas was released, i.e. the topography, the degree of its compaction with obstacles, as well as the infrastructure of the gas leakage environment and other factors affecting the gas-air mixing process. The dispersion of LNG vapours into the environment has been extensively studied both numerically and experimentally [23-28]. The research was performed in order to analyse hazardous events involving LNG and to obtain a comprehensive database for numerical research. A wide range of experiments were conducted for different leak rates, spill sizes and terrain characteristics. However, most of them were carried out in desert areas with high air temperature and low humidity (temperature $>30^{\circ} \mathrm{C}$ and relative humidity $<30 \%$ ). Air humidity $(\mathrm{RH})$ influences the dispersion of LNG vapours and should be included in the research, as LNG shipping and receiving terminals are usually located in coastal areas, where the ambient air is usually very humid ( $\mathrm{RH}>50 \%$ ) [12]. The probability of fog formation na gruntem, aż do bardzo małego na obrzeżach chmury. Maksymalne stężenie gazu ziemnego $\mathrm{w}$ chmurze zależy głównie od całkowitej objętości powietrza zmieszanego z gazem oraz szybkości mieszania. Ta z kolei zależna jest od klasy stabilności Pasquilla oraz stopnia turbulencji podczas procesu mieszania. Rozmiar utworzonej chmury gazu ziemnego zależy przede wszystkim od masy uwolnionego LNG, czasu jego dyspersji oraz warunków atmosferycznych. Na początku dyspersji LNG, większa część objętości chmury będzie zawierała stężenie gazu wyższe niż GGW. Jednakże na obrzeżach chmury mogą utworzyć się obszary mieszaniny w zakresie palności tzn. stężenie gazu będzie pomiędzy DGW a GGW. Na tej podstawie można stwierdzić, że już w początkowej fazie wycieku LPG powstała mieszanina gazowo-powietrzna będzie stwarzać zagrożenie wybuchem. W momencie odparowania całej ilości LNG stężenie gazu w chmurze stopniowo będzie ulegało obniżaniu, nawet poniżej wartości DGW, a więc mieszanina nie będzie stwarzała zagrożenia wybuchem [20]. Maksymalne ciśnienie wybuchu występuje przy stężeniu stechiometrycznym metanu wynoszącym 9,5\% [22]. W uwolnionej chmurze LNG w przestrzeni otwartej, gaz ziemny spala się stosunkowo wolno, tworząc względnie małe nadciśnienia o wartości mniejszej niż 5^103 Pa [22]. Większe wartości nadciśnienia będące wynikiem wybuchu chmury LNG pojawiają się w obszarach, w których może dojść do turbulencji powstałego płomienia, tj. w rejonach o dużym stopniu zagęszczenia konstrukcji budowlanych, procesowych lub w przestrzeniach ograniczonych przeszkodami. Wartość maksymalnego ciśnienia i GGW wybuchu metanu wzrasta również przy podwyższonym ciśnieniu początkowym [18]. Maksymalne ciśnienie wybuchu zmniejsza się wraz ze wzrostem temperatury początkowej mieszaniny palnej, gdyż w podwyższonej temperaturze szybkość reakcji spalania metanu jest większa, ale całkowita masa palnego gazu w mieszaninie palnej z powietrzem jest mniejsza niż w niższych temperaturach zapewniających ciśnienie początkowe. Temperatura wybuchu metanu na wolnej przestrzeni może wynosić $1875^{\circ} \mathrm{C}$, dochodząc $w$ przestrzeni zamkniętej nawet do $2650^{\circ} \mathrm{C}$. Temperatura zapłonu LPG wynosi $-188^{\circ} \mathrm{C}$, samozapłonu $537^{\circ} \mathrm{C}$, a minimalna energia zapłonu to ok. 0,25 $\mathrm{mJ}$ [21-22]. Obliczeniowa dynamika płynów (ang. computional fluid dynamics, CFD) umożliwia modelowanie procesu mieszania par LNG i powietrza z uwzględnieniem termodynamicznych właściwości każdego składnika w zależności od temperatury i dynamiki płynów. Technika CFD pozwala na uwzględnienie charakterystyki terenu, na którym doszło do uwolnienia gazu tzn. zarówno ukształtowanie terenu, stopień jego zagęszczenia przeszkodami, jak też infrastrukturę otoczenia wycieku gazu i inne czynniki wpływające na proces mieszania się gazu z powietrzem. Dyspersja par LNG do otoczenia została szeroko zbadana zarówno numerycznie, jak i eksperymentalnie [23-28]. Badania zostały wykonane w celu analizy zdarzeń niebezpiecznych z udziałem LNG i uzyskania kompleksowej bazy danych do badań numerycznych. Eksperymenty były prowadzone w szerokim zakresie dla różnych szybkości wycieków, rozmiarów rozlewisk i charakterystyki terenu. Jednak większość z nich została przeprowadzona na terenach pustynnych, o dużej temperaturze powietrza i małej wilgotności (temperatura $>30^{\circ} \mathrm{C}$ i wilgotność względna < 30\%). Wilgotność powietrza $(\mathrm{RH})$ wpływa na dyspersję par LNG i powinna być uwzględniana $w$ badaniach, gdyż 
following an accidental release of LNG in these areas is significantly high. A cloud of fog that mixes with LNG vapours is commonly confused with a trace of an LNG cloud of vapours. The experimental studies by Cormier et al. [17] show different sizes of the visible gas cloud captured by a VHS and infrared camera. The actual size of the LNG vapour cloud as recorded by the infrared camera was much larger than that of the fog cloud, meaning a larger area of LNG flammable gas. Fog is an aerosol consisting of airborne droplets of water or ice crystals when water vapour condenses or solidifies due to low temperature. Often, in the simulations, the fog is treated only as liquid water droplets, and the ice formation process is not taken into account as dominant in the dispersion of LNG vapour in large and open spaces and usually above its freezing point. In case of low air humidity (e.g. $\mathrm{RH}<30 \%$ ), the LNG vapour cloud moves beyond the visible fog, which was confirmed by the experimental results. However, in scenarios with high air humidity (e.g. $\mathrm{RH}>50 \%$ ), the fog may overtake and dominate the LNG vapour cloud. The formation of fog in the area of LNG release may reduce the effect of vapour dispersion of this gas and slow down the process of its dispersion to the environment. As shown in the research [29], the turbulence models selected for simulation and the introduced boundary conditions have the greatest impact on modelling the dispersion of this gas.

Fire and explosion hazards of LNG during its transport, storage or use mainly result from its flammability, high density of liquid natural gas at a boiling point of approx. $-162^{\circ} \mathrm{C}$ at atmospheric pressure. LNG, when released as a combustible cryogenic liquid, forms a large-volume gas cloud and, when mixed with air, forms an explosive mixture. The main hazards related to the storage and transport of LNG include fires and explosions that may occur as a result of an LNG leak and spill in the presence of an effective ignition source. If not ignited, the LNG will evaporate, expand and eventually form a vapour cloud that disperses into the atmosphere. In case of LNG ignition, it is possible to create a flash fire, a cloud of vapours with air, jet fire, a fire on a spill, or an explosion of a mixture of vapours with air $[30,12]$. The consequences of LNG fires and explosions depend mainly on the temperature of the flammable mixture and the initial composition of the gas, as well as on the diameter of the spill fire [31-32]. Additional flame turbulence in the cloud of a combustible mixture may result from the presence of LPG aerosol particles in the cloud or the presence of a space crowded with obstacles (e.g. process installations) and cause higher overpressure values during explosions. The size of the released LNG cloud will largely depend on the mass of the released LNG, the time of its release and diffusion, and weather conditions. In the open space in the formed LNG cloud, combustible gas burns slowly, thus generating low overpressure [31]. Table 1 presents the possible types of fire hazards caused by LNG. terminale wysyłkowe i odbiorcze LNG zwykle znajdują się na obszarach przybrzeżnych, gdzie powietrze otoczenia jest przeważnie bardzo wilgotne $(\mathrm{RH}>50 \%)$ [12]. Prawdopodobieństwo powstania mgły po przypadkowym uwalnianiu LNG na tych terenach jest znacząco wysokie. Chmura mgły, która miesza się z oparami LNG jest powszechnie mylona ze śladem chmury par LNG. Badania eksperymentalne przeprowadzone przez Cormier'a i in. [17] pokazują różne wielkości widocznego obłoku gazu zarejestrowanego przez kamerę VHS i w podczerwieni. Rzeczywista wielkość chmury pary LNG zarejestrowana przez kamerę w podczerwieni była znacznie większa niż chmura mgły, co oznacza większy obszar palnego gazu. Mgła jest aerozolem składającym się z unoszących się w powietrzu kropelek wody lub kryształków lodu, gdy para wodna skrapla się lub zestala z powodu niskiej temperatury. Często w symulacjach mgła jest traktowana wyłącznie jako kropelki wody w stanie ciekłym. Proces tworzenia się lodu nie jest brany pod uwagę jako dominujący podczas dyspersji pary LNG na dużych oraz otwartych przestrzeniach i zwykle powyżej temperatury jego zamarzania. W przypadku niskiej wilgotności powietrza (np. $\mathrm{RH}<30 \%$ ) obłok par LNG przemieszcza się poza widoczną mgłę, co potwierdziły wyniki eksperymentalne. Jednak w scenariuszach o wysokiej wilgotności powietrza (np. $\mathrm{RH}>50 \%$ ), mgła może wyprzedzić i zdominować chmurę par LNG. Tworzenie się mgły w obszarze uwolnienia LNG może zmniejszyć efekt dyspersji par tego gazu i spowolnić proces jego rozpraszania do otoczenia. Jak wykazano w badaniach [29], wybrane do symulacji modele turbulencji i wprowadzone warunki graniczne najbardziej wpływają na modelowanie dyspersji tego gazu.

Zagrożenia pożarowo-wybuchowe LNG podczas jego transportu, magazynowania czy też stosowania wynikają głównie z jego palności, dużej gęstości ciekłego gazu ziemnego w temperaturze wrzenia ok. $-162^{\circ} \mathrm{C}$ przy ciśnieniu atmosferycznym. LNG jako palna ciecz kriogeniczna po uwolnieniu tworzy obłok gazu o dużej objętości, natomiast po wymieszaniu z powietrzem tworzy mieszaninę wybuchową. Do głównych zagrożeń związanych z magazynowaniem i transportem LNG należy zaliczyć pożary i wybuchy, które mogą powstać w wyniku wycieku i rozlania LNG w obecności efektywnego źródła zapłonu. W przypadku braku zapłonu LNG wyparuje, rozprzestrzeni się i ostatecznie utworzy chmurę pary, która rozproszy się $w$ atmosferze. W przypadku zapłonu LNG możliwe jest powstanie pożaru błyskawicznego chmury par z powietrzem, pożaru strumieniowego, pożaru rozlewiska czy wybuchu mieszaniny par z powietrzem [30,12]. Konsekwencje pożarów i wybuchów LNG zależą głównie od temperatury mieszaniny palnej i składu początkowego gazu, a także od średnicy pożaru rozlewiska [31-32]. Dodatkowa turbulencja płomienia w chmurze mieszaniny palnej może wynikać z obecności cząsteczek aerozolu LPG w chmurze czy też występowania przestrzeni zatłoczonej przeszkodami (np. instalacji procesowych) i powodować wyższe wartości nadciśnień podczas wybuchów. Rozmiar uwolnionej chmury LNG będzie $w$ dużej mierze uzależniony od masy uwolnionego LNG, czasu jego uwolnienia i dyfuzji oraz warunków atmosferycznych. Na przestrzeni otwartej w powstałej chmurze LNG gaz palny spala się wolno, tym samym generując niskie nadciśnienia [31]. W tabeli 1 przedstawione zostały możliwe rodzaje zagrożeń pożarowych powodowanych przez LNG. 
Table 1. Summary of the main types of fire hazards caused by LNG

Tabela 1. Zestawienie głównych typów zagrożeń pożarowych powodowanych przez LNG

\begin{tabular}{|c|c|c|c|c|}
\hline Type / Rodzaj & $\begin{array}{l}\text { Hazard type / } \\
\text { Typ zagrożenia }\end{array}$ & Observation / Obserwacje & $\begin{array}{l}\text { Possible worst case scenario / } \\
\text { Możliwy najgorszy scenariusz }\end{array}$ & $\begin{array}{l}\text { Hazardous effect / } \\
\text { Efekt niebezpieczne }\end{array}$ \\
\hline 1 & 2 & 3 & 4 & 5 \\
\hline \multirow{3}{*}{ Fire / Pożar } & $\begin{array}{l}\text { Flash fire, FF / } \\
\text { Pożar obłoku FF) }\end{array}$ & $\begin{array}{c}\text { Deflagration combustion of } \\
\text { a combustible mixture without generating } \\
\text { a destructive pressure wave / Deflagracyjne } \\
\text { spalanie mieszaniny palnej bez wytworzenia } \\
\text { niszczącej fali ciśnienia }\end{array}$ & $\begin{array}{l}\text { LNG leak, formation of a cloud of va- } \\
\text { pours mixed with air and its ignition } \\
\text { / Wyciek LNG, powstanie obłoku } \\
\text { par wymieszanej z powietrzem i jej } \\
\text { zapłon }\end{array}$ & \multirow{3}{*}{$\begin{array}{l}\text { Thermal radiation } \\
\text { flux and toxic } \\
\text { products of thermal } \\
\text { decomposition } \\
\text { and combustion / } \\
\text { Strumień promie- } \\
\text { niowania cieplnego } \\
\text { oraz toksyczne } \\
\text { produkty rozkładu } \\
\text { termicznego } \\
\text { i spalania }\end{array}$} \\
\hline & $\begin{array}{c}\text { Jet fire (JF) / } \\
\text { Pożar strumieniowy } \\
\text { (JF) }\end{array}$ & $\begin{array}{l}\text { A jet-shaped flame formed at the outlet of } \\
\text { gas flowing from a pressure vessel through } \\
\text { a small opening / Płomień w kształcie stru- } \\
\text { mienia powstający u wylotu gazu wypływają- } \\
\text { cego ze zbiornika ciśnieniowego przez mały } \\
\text { otwór }\end{array}$ & $\begin{array}{l}\text { Heating by a flame of the tank, } \\
\text { weakening the strength of the tank } \\
\text { or exceeding the allowable pressure } \\
\text { in the tank / Ogrzewanie płomieniem } \\
\text { zbiornika, osłabienie wytrzymałości } \\
\text { zbiornika lub przekroczenie dopusz- } \\
\text { czalnego ciśnienia w zbiorniku }\end{array}$ & \\
\hline & $\begin{array}{l}\text { Cryogenic fluid spill } \\
\text { fire / } \\
\text { Pożar rozlewiska } \\
\text { cieczy kriogenicznej }\end{array}$ & $\begin{array}{l}\text { Combustion of a flammable mixture, i.e. LNG } \\
\text { vapours mixed with air / Spalanie miesza- } \\
\text { niny palnej tzn. par LNG wymieszanych } \\
\text { z powietrzem }\end{array}$ & $\begin{array}{l}\text { Ignition of the flammable mixture } \\
\text { resulting from the evaporation of } \\
\text { LNG vapours / Zapalenie mieszaniny } \\
\text { palnej powstałej } \\
\text { z odparowania par LNG }\end{array}$ & \\
\hline \multirow{4}{*}{$\begin{array}{l}\text { Explosion / } \\
\text { Wybuch }\end{array}$} & $\begin{array}{l}\text { In a confined space } \\
\text { (VCE) / W ograni- } \\
\text { czonej przestrzeni } \\
\text { (VCE) }\end{array}$ & $\begin{array}{l}\text { Heterogeneous, usually deflagration combu- } \\
\text { stion of a flammable mixture in a confined } \\
\text { space with the formation of a pressure wave } \\
\text { or a shock wave / Heterogeniczne, zwykle } \\
\text { deflagracyjne spalanie mieszaniny palnej } \\
\text { w ograniczonej przestrzeni z powstaniem fali } \\
\text { ciśnienia lub fali uderzeniowej }\end{array}$ & $\begin{array}{l}\text { Outflow of gas, liquefied gas or } \\
\text { superheated liquid from the pressure } \\
\text { vessel, possible flame turbulence and } \\
\text { transition to detonation / Wypływ } \\
\text { gazu, gazu skroplonego lub przegrza- } \\
\text { nej cieczy ze zbiornika ciśnieniowe- } \\
\text { go, możliwość turbulencji płomienia } \\
\text { i przejścia w detonację }\end{array}$ & $\begin{array}{l}\text { Pressure wave, heat } \\
\text { radiation, debris / } \\
\text { Fala ciśnienia, } \\
\text { promieniowanie } \\
\text { cieplne, odłamki }\end{array}$ \\
\hline & $\begin{array}{l}\text { In the open space } \\
\text { (UVCE) / W otwartej } \\
\text { przestrzeni (UVCE) }\end{array}$ & $\begin{array}{l}\text { Heterogeneous combustion of a flammable } \\
\text { mixture with the formation of a pressure wave / } \\
\text { Heterogeniczne spalanie mieszaniny palnej } \\
\text { z powstaniem fali ciśnienia }\end{array}$ & $\begin{array}{l}\text { Dispersion and delayed ignition / } \\
\text { Dyspersja oraz zapłon opóźniony }\end{array}$ & $\begin{array}{l}\text { Pressure wave, heat } \\
\text { radiation, debris / } \\
\text { Fala ciśnienia, } \\
\text { promieniowanie } \\
\text { cieplne, odłamki }\end{array}$ \\
\hline & $\begin{array}{l}\text { Expanding steam } \\
\text { from a boiling liquid } \\
\text { (BLEVE) / Ekspandu- } \\
\text { jącej pary z wrzącej } \\
\text { cieczy (BLEVE) }\end{array}$ & $\begin{array}{l}\text { Sudden rupture of the tank with the ejection of } \\
\text { expanding vapours of the liquid at a liquid tem- } \\
\text { perature higher than its boiling point at normal } \\
\text { atmospheric pressure, resulting from a large } \\
\text { multi-site damage to the tank / Nagłe roze- } \\
\text { rwanie zbiornika z wyrzutem rozprężających } \\
\text { się par cieczy w temp. cieczy wyższej od jej } \\
\text { temperatury wrzenia przy normalnym ciśnieniu } \\
\text { atmosferycznym, powstały w wyniku dużego } \\
\text { wielomiejscowego uszkodzenia zbiornika }\end{array}$ & $\begin{array}{l}\text { External fire, e.g. spillages or JF, } \\
\text { containing a liquefied gas tank within } \\
\text { its reach, creating a fireball / } \\
\text { Zewnętrzny pożar np. rozlewiska lub } \\
\text { JF, obejmujący swoim zasięgiem } \\
\text { zbiornik z gazem skroplonym, } \\
\text { utworzenia kuli ognia }\end{array}$ & $\begin{array}{l}\text { Pressure wave, heat } \\
\text { radiation, debris / } \\
\text { Fala ciśnienia, } \\
\text { promieniowanie } \\
\text { cieplne, odłamki }\end{array}$ \\
\hline & $\begin{array}{l}\text { Physical explosion / } \\
\text { Wybuch fizyczny }\end{array}$ & $\begin{array}{l}\text { Failure to observe the parameters of the tank } \\
\text { strength, error when filling the tank, exceeding } \\
\text { the allowable pressure in the tank, exceeding } \\
\text { the maximum temperature in the system with } \\
\text { overpressure / Nieprzestrzeganie parametrów } \\
\text { wytrzymałości zbiornika, błąd przy napeł- } \\
\text { nianiu zbiornika, przekroczenie w zbiorniku } \\
\text { dopuszczalnego ciśnienia, przekroczenie } \\
\text { maksymalnej temperatury w układzie z nad- } \\
\text { ciśnieniem }\end{array}$ & $\begin{array}{l}\text { An external fire, e.g. a spill or a JF, } \\
\text { covering the liquefied gas tank } \\
\text { with its reach / Zewnętrzny pożar } \\
\text { np. rozlewiska lub JF, obejmujący } \\
\text { swoim zasięgiem zbiornik z gazem } \\
\text { skroplonym }\end{array}$ & $\begin{array}{c}\text { Pressure wave, heat } \\
\text { radiation, debris / } \\
\text { Fala ciśnienia, } \\
\text { promieniowanie } \\
\text { cieplne, odłamki }\end{array}$ \\
\hline
\end{tabular}


Liquefied natural gas does not pose a threat in the form of environmental contamination. Upon contact with air, LNG evaporates and is thinned in the air. Therefore, it is much less harmful and dangerous fuel than crude oil or LPG. The average heat of combustion of $L N G$ is about $39.26 \mathrm{MJ} / \mathrm{m}^{3}$, which in terms of mass amounts to $54 \mathrm{MJ}^{\mathrm{kg}} \mathrm{kg}^{-1}$. This value is close to the value of heat of combustion

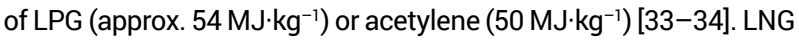
as a fuel is characterized by a relatively high volume of energy density compared to typical fuels such as crude oil or LPG, and in addition, during combustion it emits relatively small amounts of nitrogen oxides compared to diesel or gasoline or fossil fuels [35]. The low temperature of LPG compared to the ambient temperature can cause frostbite when it comes into direct contact with the human skin. Materials exposed to low temperature must have sufficient mechanical properties at the lowest liquefied gas temperature. This threat has a limited range depending on the size of the spill. The cryogenic plant operates at the temperatures much lower than the ambient temperature, therefore all insufficiently insulated parts will be covered with frost. Water and other fluids, when they freeze, can block valves and piping, which should be properly designed, cleaned, and drained. LNG storage tanks are pressure tanks usually built of double walls, internal and external, between which there is a vacuum, ensuring good thermal insulation from the environment. The figure below shows follow-up scenarios, which takes into account the sequence of probable events after an LNG leak. Usually, during fires of LNG tanks, jet fires are most often observed, less often BLEVE or fires of cryogenic fluid spill. The publication of Lee [36] shows the influence of technological conditions of LNG regasification on the simulation results of LNG emissions depending on the size of the source of leakage into the environment and the probability of ignition on vessels. A quantitative risk assessment (QRA) of the floating unit regasification process was also performed using the frequencies and effects of an LNG explosion fire. A probabilistic safe distance for the selected lengths of flames in a jet fire was estimated, together with an analysis of the consequences of hazardous events and risk assessment. The analysis of stream fires showed that the risk of LNG leakage horizontally in relation to the vertical one was higher, while the risk of this gas explosion was similar in both directions.
Skroplony gaz ziemny nie stanowi zagrożenia w postaci skażenia środowiska. W przypadku kontaktu z powietrzem, LNG odparowuje i rozrzedza się w powietrzu. Zatem jest on znacznie mniej szkodliwym i niebezpiecznym paliwem niż ropa naftowa czy LPG. Ciepło spalania $L N G$ wynosi średnio ok. $39,26 \mathrm{MJ} / \mathrm{m}^{3}$, co w przeliczeniu na masę wynosi $54 \mathrm{MJ}^{\mathrm{kg}}{ }^{-1}$. Wartość ta zbliżona jest do wartości ciepła spalania gazu LPG (ok. $54 \mathrm{MJ} \cdot \mathrm{kg}^{-1}$ ) czy acetylenu $\left(50 \mathrm{MJ} \mathrm{kg}^{-1}\right)$ [33-34]. LNG jako paliwo charakteryzuje się stosunkowo dużą objętościowo gęstością energii w porównaniu do typowych paliw jak ropa naftowa czy LPG, a oprócz tego podczas spalania wydziela stosunkowo małe ilości tlenków azotu w porównaniu do oleju napędowego lub benzyny czy paliw kopalnianych [35]. Niska temperatura płynnego gazu ziemnego w porównaniu z temperaturą otoczenia może spowodować odmrożenia przy bezpośrednim kontakcie ze skórą człowieka. Materiały narażone na niską temperaturę muszą posiadać wystarczające właściwości mechaniczne w najniższej temperaturze skroplonego gazu. To zagrożenie ma ograniczony zasięg zależny od wielkości rozlewiska. Instalacja kriogeniczna działa w temperaturach znacznie niższych niż otoczenie, dlatego wszystkie niedostatecznie zaizolowane części zostaną pokryte szronem. Woda i inne płyny po zamarznięciu mogą blokować zawory i przewody rurowe, które powinny być prawidłowo zaprojektowane, czyszczone i osuszane. Zbiorniki magazynujące LNG to zbiorniki ciśnieniowe zbudowane najczęściej z podwójnych ścianek, wewnętrznych i zewnętrznych, pomiędzy którymi panuje próżnia, zapewniająca dobrą izolację termiczną od otoczenia. Na poniższej rycinie zostało przedstawione drzewo zdarzeń scenariuszy następczych, które uwzględnia kolejność prawdopodobnych zdarzeń po wycieku LNG. Zazwyczaj podczas pożarów zbiorników z LNG najczęściej można zaobserwować pożary strumieniowe, rzadziej BLEVE czy też pożary rozlewiska cieczy kriogenicznej. W publikacji Lee`a [36] ukazano wpływ warunków technologicznych prowadzenia regazyfikacji LNG na wyniki symulacji emisji LNG w zależności od rozmiarów źródła wycieku do środowiska i prawdopodobieństwo zapłonu na jednostkach pływających. Wykonano również ilościową ocenę ryzyka (ang. quantitative risk assessment, QRA) procesu regazyfikacji pływającej jednostki wykorzystując częstotliwości i skutki pożaru wybuchu LNG. Oszacowano probabilistyczną bezpieczną odległość dla wytypowanych długości płomieni w pożarze strumieniowym wraz z analizą konsekwencji zdarzeń niebezpiecznych i oceną ryzyka. Analiza pożarów strumieniowych wykazała, że ryzyko wycieku poziomego LNG w stosunku do pionowego było większe, podczas gdy ryzyko wybuchu tego gazu było zbliżone w obu kierunkach. 


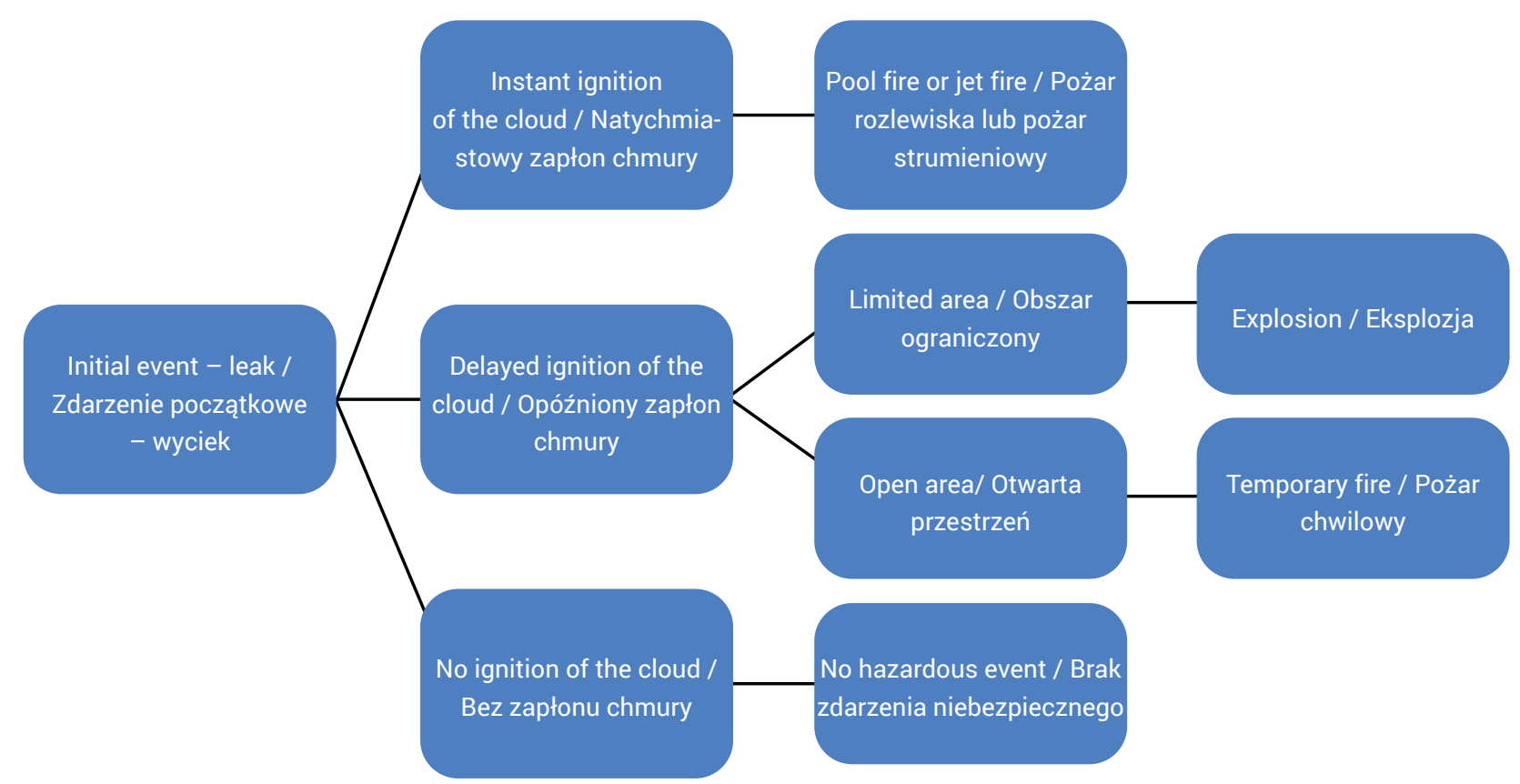

Figure 1. Follow-up scenarios involving LNG

Rycina 1. Drzewo zdarzeń scenariuszy następczych z udziałem LNG

Source: Own elaboration.

Źródło: Opracowanie własne.

\section{LNG storage and road transport}

Under fire conditions, LNG tanks and installations may pose a risk of failure or explosion. In order to ensure adequate safety in industrial plants in the event of such a threat, the European Commission introduced Directive 2012/18/EC also known as Seveso III [37]. It contains requirements for the prevention of major accidents involving hazardous substances and ways to reduce their effects on human health and the environment. According to Seveso III, the main hazardous installations are divided into hazard levels - lower, applicable to installations with more than 50 tons of hazardous substance (e.g. LNG), and higher, for installations handling more than 200 tons. Lower - and upper-tier establishments - in line with the Seveso III directive - must prepare a safety report showing that all major hazards in the establishment have been identified and the necessary safety measures have been taken to prevent major malfunctions and accidents. Other obligations under the directive include establishing a safety management system on-site, an on-site emergency plan, and informing the public about the main hazards of a nearby site, as well as taking appropriate safety measures.

With the introduction of Seveso III Directive, normative acts were created that define the methods of safe LNG storage. The PN-EN 1473:2021-10 [38] standard defines the guidelines for the design, construction and operation of onshore LNG installations storing over 200 tons of LNG on land for liquefaction, storage, evaporation, transmission and handling of LNG and natural gas (NG). The regulatory boundaries are the LNG entry/exit through

\section{Magazynowanie i transport drogowy LNG}

Zbiorniki LNG wraz z instalacjami w warunkach pożaru mogą stwarzać zagrożenie związane $z$ awarią czy wybuchem. W celu zapewnienia odpowiedniego bezpieczeństwa w zakładach przemysłowych w przypadku wystąpienia takiego zagrożenia Komisja Europejska wprowadziła dyrektywę 2012/18/WE znaną również jako Seveso III [37]. Zawiera ona wymagania dotyczące zapobieganie poważnym awariom z udziałem substancji niebezpiecznych oraz sposoby zmniejszenia ich skutków mających wpływ na ludzkie zdrowie i środowisko. Według Seveso III główne niebezpieczne instalacje są podzielone na poziomy zagrożenia - niższy, mający zastosowanie do instalacji z ilością substancji niebezpiecznej (np. LNG) ponad 50 ton i wyższy, dla instalacji obsługujących więcej niż 200 ton. Zakłady zwiększonego i dużego ryzyka - zgodne z dyrektywą Seveso III - muszą przygotować raport o bezpieczeństwie wykazujący, że wszystkie główne zagrożenia w zakładzie zostały zidentyfikowane i podjęto niezbędne środki bezpieczeństwa, aby zapobiec poważnym awariom i wypadkom. Inne zobowiązania wynikające $z$ dyrektywy to ustalenie systemu zarządzania bezpieczeństwem w zakładzie, wewnętrznego planu awaryjnego oraz informowanie opinii publicznej o głównych zagrożeniach występujących w pobliskim zakładzie i przedsięwzięcie odpowiednich środków bezpieczeństwa.

Wraz z wprowadzeniem dyrektywy Seveso III powstały akty normatywne określające sposoby bezpiecznego magazynowania LNG. Norma PN-EN 1473:2021-10 [38] określa wytyczne dotyczące projektowania, budowy i obsługi lądowych instalacji LNG magazynujących ponad 200 ton LNG na lądzie, służących do 
the ship's manifold, including a combination of vapour return and tanker loading/unloading and vapour return, a combination of rail car loading/unloading and vapour return, as well as natural gas input and output boundary through pipeline systems. The application of these guidelines requires the assessment of acceptable levels of risk of loss of life and property both outside and within the boundaries of the facility. On the other hand, the PN-EN 13645: 2008 [39] standard issued risk assessment requirements and examples for installations with a small storage capacity (from 5 tons to 200 tons). These standards are optional and are intended to improve safety in LNG-consuming facilities, in particular at reloading and storage depots and gas supply stations for vehicles. The American National Fire Protection Association (NFPA) introduced the NFPA 59A, 2019 [40] standard for LNG storage and transshipment, containing guidelines for the location, design, construction, maintenance and operation of LNG production, storage and handling facilities.

The European ADR agreement of 2021, regulating the international road transport of dangerous goods [41], contains the rules of operation for loading LNG tanks. This document is divided into two annexes covering general provisions and provisions concerning equipment and transport operations. It includes, among others, the requirements for the design, construction, control and testing of LNG tanks. LNG vehicles must meet the requirements of the PN EN ISO 20421-2 [42] standard issued to specify operational requirements for large transport cryogenic tanks with vacuum insulation. These performance requirements include commissioning, charging, refrigerant collection, in-plant transportation, storage, maintenance, periodic inspection and emergency procedures. Additional requirements may apply for the transport of these tanks by public roads, rail, inland waterway, sea and air transport; they are specified in specific provisions. The European standard PN EN 13530-2 [43] presents specifications for the design, production, control and testing of large vacuum insulated tanks with a capacity of more than 1000 litres mounted on road vehicles, permanently or with the possibility of disassembly, with the exception of tanks for toxic liquids.

\section{Experimental study of a 200 I LNG tank under fire conditions}

As part of the DOB-BIO6/02/50/2014 project entitled "Development of methods for neutralizing the risk of explosion in selected technical gas tanks, including alternative power sources in a fire environment for the needs of rescuers participating in rescue and firefighting operations" financed by the National Centre For Research and Development, one experiment was performed with a 200-liter vacuum-insulated cryogenic tank containing LNG. The test was carried out at the Artillery and Armament Training skraplania, magazynowania, odparowywania, przesyłu i obsługi LNG i gazu ziemnego (NG). Wyznaczone granice obowiązywania przepisów to wejście/wyjście LNG przez kolektor statku, włączając połączenie powrotu oparów i załadunku/rozładunku cysterny oraz powrót oparów, a także połączenie załadunku/ rozładunku wagonów kolejowych i powrót oparów, oraz granica wejścia i wyjścia gazu ziemnego przez systemy rurociągów. Zastosowanie tych wytycznych wymaga oszacowania akceptowalnych poziomów ryzyka utraty życia oraz mienia zarówno na zewnątrz, jak i wewnątrz granic zakładu. Natomiast w normie PN-EN 13645:2008 [39] wydano wymagania dotyczące oceny ryzyka i przykłady dla instalacji o małej pojemności magazynowej (od 5 ton do 200 ton). Standardy te są opcjonalne i mają na celu poprawę bezpieczeństwo w obiektach użytkujących LNG, w szczególności na terenie baz przeładunkowo-magazynowych oraz stacji zasilania gazem pojazdów. Amerykańskie Narodowe Stowarzyszenie Ochrony Przeciwpożarowej (ang. National Fire Protection Association, NFPA) wprowadziło standard NFPA 59A, 2019 [40] dotyczący magazynowania i przeładunku LNG, zawierający wytyczne z zakresu lokalizacji, projektowania, budowy, utrzymania i eksploatacji obiektów produkujących, przechowujących i obsługujących LNG.

Umowa europejska ADR z 2021 r. regulująca międzynarodowy przewóz drogowy towarów niebezpiecznych [41] zawiera zasady eksploatacji przy załadunku cystern LNG. Dokument ten podzielono na dwa załączniki obejmujące przepisy ogólne i przepisy dotyczące sprzętu i operacji transportowych. Zawiera m.in. wymagania dotyczące projektowania, budowy i kontroli oraz badania zbiorników LNG. Ciężarówki na LNG muszą spełniać wymagania normy PN EN ISO 20421-2 [42] wydanej w celu specyfikacji wymagań eksploatacyjnych dla dużych transportowych zbiorników kriogenicznych z izolacją próżniową. Te wymagania eksploatacyjne obejmują oddawanie do użytkowania, napełnianie, pobieranie czynnika, transport wewnątrz zakładu, magazynowanie, konserwację, kontrolę okresową i procedury awaryjne. Do celów transportu tych zbiorników na drogach publicznych, koleją, w żegludze śródlądowej, transporcie morskim i powietrznym, mogą mieć zastosowanie dodatkowe wymagania; są one określone w przepisach szczegótowych. Norma europejska PN EN 13530-2 [43] przedstawia specyfikacje dotyczące projektowania, wytwarzania kontroli i badań dużych zbiorników izolowanych próżnią o pojemności powyżej 1000 litrów montowanych na pojazdach drogowych, na stałe lub z możliwością demontażu z wyjątkiem zbiorników na płyny toksyczne.

\section{Badanie eksperymentalne zbiornika 200 I LNG w warunkach pożarowych}

W ramach projektu DOB-BIO6/02/50/2014 pt.„Opracowanie metod neutralizacji zagrożenia wybuchu wytypowanych zbiorników z gazami technicznymi, w tym alternatywnymi źródłami zasilania w środowisku pożarowym na potrzeby ratowników biorących udział w akcjach ratowniczo-gaśniczych" finansowanego przez Narodowe Centrum Badan i Rozwoju wykonano jeden eksperyment z udziałem 200 I zbiornika kriogenicznego izolowanego próżnią zawierającego LNG. Badania przeprowadzono 
Centre in Torun. As a leader, the following institution participated in the research consortium - the Main School of Fire Service, then as members - the Warsaw University of Technology, Gdańsk University of Technology, Scientific and Research Centre for Fire Protection - National Research Institute, CORONA Sp. z o.o. The purpose of this research was to test the actual explosion of the selected LNG tank, including the determination of the impact range of the fragments of the exploding tank, determination of the fire zone and the maximum pressure in the tank.

The LNG tank was placed in a tank filled with a 2:1 mixture of gasoline and diesel oil with a volume of about 20 litres (see Figure 2). The initial vapour pressure in the LNG tank with vacuum insulation was 14.6 bar. After 3 minutes of heating the tank, methane was released through the safety valve. The released gas ignited and burned with a quiet flame directed upwards for a maximum length of $5 \mathrm{~m}$. In the final phase of the experiment, after $11 \mathrm{~min}$ utes, the tank was shot twice (see Figure 3). The moments at which the tank was shot are marked on the diagram of pressure changes in the cylinder (see Figure 4). The analysis of the technical condition of the LNG tank showed the breaking of the plate securing the vacuum jacket of the apparatus after the experiment (see Figure 5).

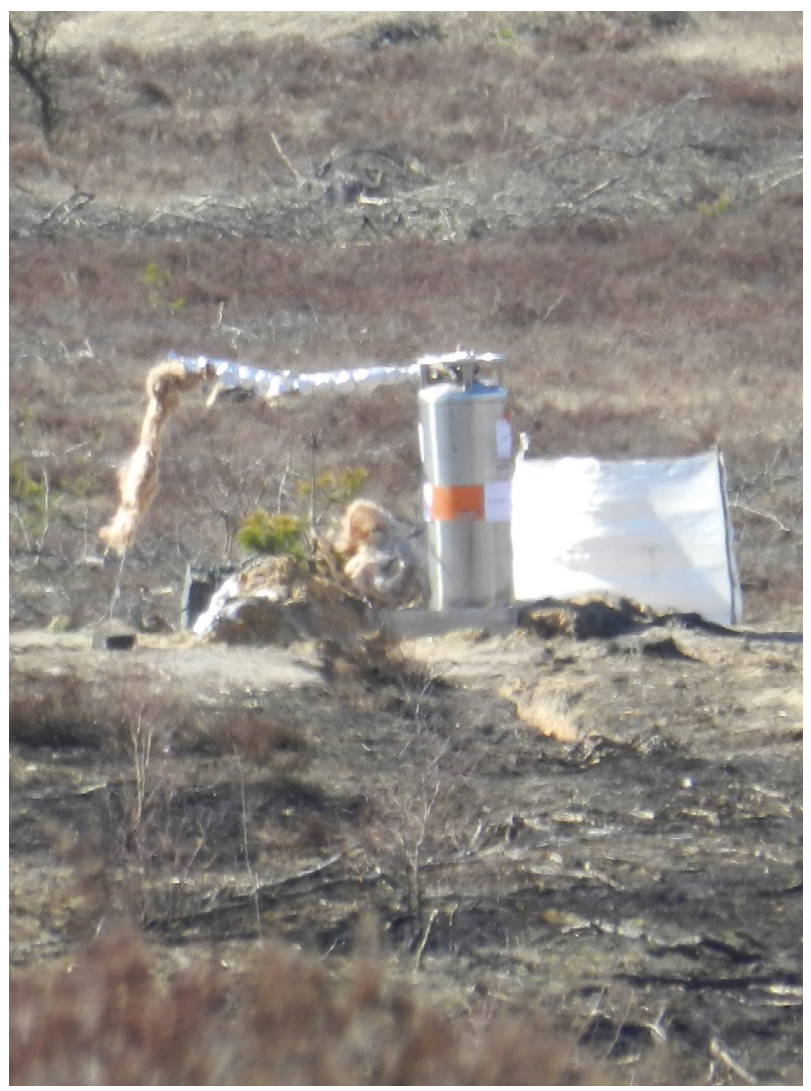

Figure 2. LNG tank placed in a tank with gasoline and diesel fuel Rycina 2. Zbiornik z LNG ustawiony w wannie z benzyną i olejem napędowym

Source: Own elaboration.

Źródło: Opracowanie własne. na poligonie Centrum Szkolenia Artylerii i Uzbrojenia w Toruniu. W konsorcjum badawczym brali udział jako lider - Szkoła Główna Służby Pożarniczej, następnie jako członkowie Politechnika Warszawska, Politechnika Gdańska, Centrum Naukowo-Badawcze Ochrony Przeciwpożarowej im. Józefa Tuliszkowskiego - Państwowy Instytut Badawczy, CORONA Sp. z o.o. Celem realizacji tych badań było przeprowadzenie badania rzeczywistego wybuchu wytypowanego zbiornika LNG, w tym określenie zasięgu rażenia odłamkami eksplodującego zbiornika, wyznaczenie strefy ognia oraz ciśnienia maksymalnego w zbiorniku.

Zbiornik z LNG umieszczony został w zbiorniku wypełnionym mieszaniną benzyny i oleju napędowego w stosunku 2:1 o objętości ok. 20 I (zob. ryc. 2). Ciśnienie początkowe par w zbiorniku LNG z izolacją próżniową wynosiło 14.6 barów. Po 3 minutach ogrzewania zbiornika nastąpiło uwolnienie metanu przez zawór bezpieczeństwa. Uwolniony gaz zapalił się i palił się spokojnym płomieniem skierowanym w górę na długości maksymalnie $5 \mathrm{~m}$. W końcowej fazie eksperymentu po 11 minutach zbiornik został dwukrotnie przestrzelony (zob. ryc. 3). Momenty przestrzelenia zbiornika zostały zaznaczone na wykresie zmian ciśnienia w butli (zob. ryc. 4). Analiza stanu technicznego zbiornika LNG wykazała zerwanie płytki zabezpieczającej próżniowy płaszcz aparatury po eksperymencie (zob. ryc. 5).

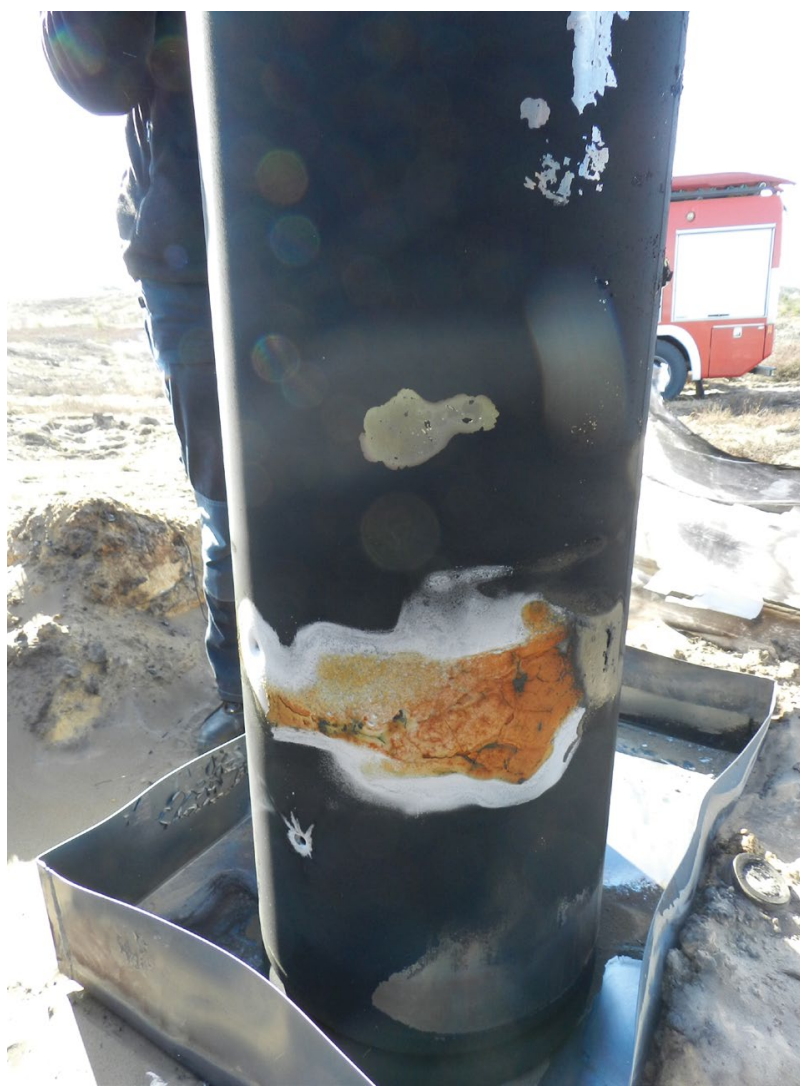

Figure 3. LNG tank after activation of the safety value and after burning Rycina 3. Zbiornik LNG po aktywacji zaworu bezpieczeństwa i spaleniu

Source: Own elaboration.

Źródło: Opracowanie własne. 


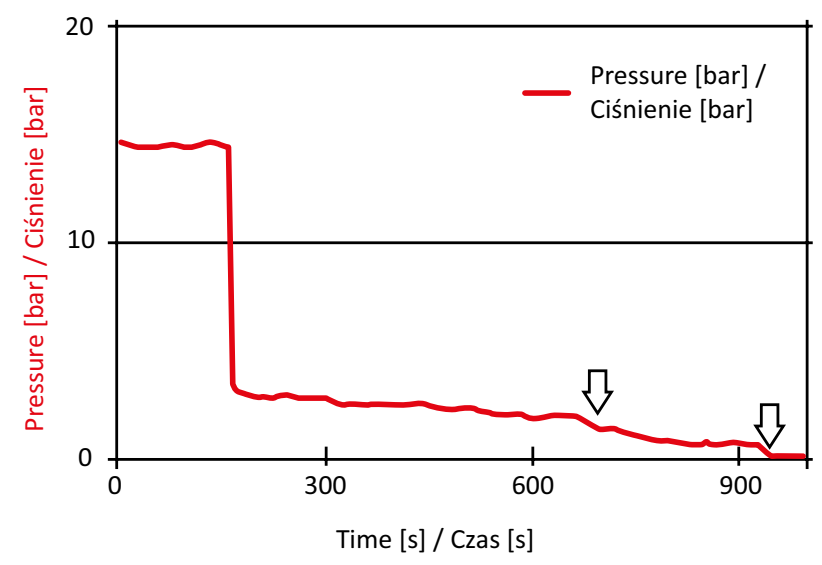

Figure 4. Pressure course in the LNG tank. The time marked with arrows shows the time when shots were fired into the tank Rycina 4. Przebieg ciśnienia w zbiorniku z LNG. Zaznaczony strzałkami czas ukazuje czas oddania strzałów do zbiornika

Source: Final report of the DOB-BIO6/02/50/2014 project.

Źródło: Raport końcowy projektu DOB-BIO6/02/50/2014.

The conducted experiment showed that the LNG tank selected for the tests did not explode under the conditions of the tested fire. The accumulated excess vapours in the tank vented through the safety valve (in this case it was a vacuum valve), formed a flammable mixture with air and ignited to form a jet fire. The gas stream fire gradually decreased with the time the fuel spill burned up and the gas burned. Hence, in the scenarios of the events involving an LNG tank, heated in a fire with a heat stream, the possibility of creating a jet flame directed upwards (not heating the tank) should be considered and during such an event an LNG tank with a capacity of 200 litres should be placed with observation for free gas burnout.

\section{Summary}

Fire and explosion hazards of LNG during its transport, storage or use result mainly from its flammability, high density of liquid LNG at its boiling point at atmospheric pressure.

Depending on the thermal exposure, heat losses to the environment under fire conditions, the type of emission, time to ignition and the type of effective ignition stimulus - a fire or explosion of a combustible mixture made of LNG is possible.

The rate of LNG leaks, the size of the spillages, air humidity, terrain characteristics (especially the congestion of obstacles) determine the dispersion of the LNG cloud and the possible effects of an explosion.

The combustion of the natural gas significantly depends on the time of applying an effective source of ignition and the time of formation of the fuel-air cloud.

In case of the ignition of LNG vapours, a flash fire of a cloud of vapours with air, jet fire, and fire of a spill or an explosion of a mixture of vapours with air or BLEVE is possible.

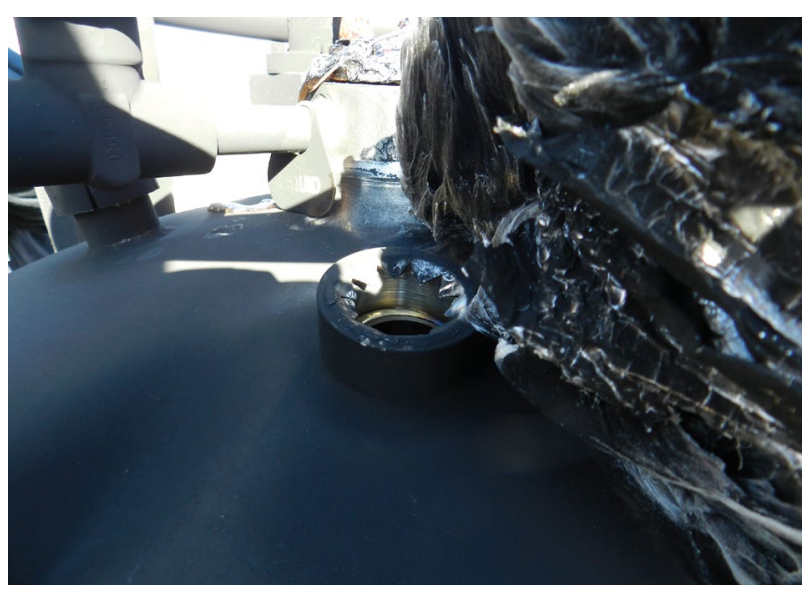

Figure 5. Broken vacuum fuse

Rycina 5. Zerwany bezpiecznik próżniowy

Source: Own elaboration.

Źródło: Opracowanie własne.

Przeprowadzony eksperyment pokazał, że wytypowanego do badań zbiornik LNG w warunkach testowanego pożaru nie uległ wybuchowi. Zgromadzony nadmiar par w zbiorniku znalazł ujście poprzez zawór bezpieczeństwa (w tym przypadku był to zawór próżniowy), utworzył mieszaninę palną z powietrzem i zapalił się, tworząc jet fire. Pożar strumienia gazu stopniowo zmniejszał się wraz z czasem wypalania rozlewiska paliwa i spalania gazu. Stąd też należy rozpatrywać w scenariuszach zdarzeń z udziałem zbiornika LNG, ogrzewanego w warunkach pożaru strumieniem ciepła możliwość tworzenia płomienia strumieniowego skierowany do góry (nie ogrzewającego zbiornik) i podczas takiego zdarzenia postawić zbiornik LNG o pojemności 200 litrów wraz z obserwacją do swobodnego wypalenia gazu.

\section{Podsumowanie}

Zagrożenia pożarowo-wybuchowe LNG podczas jego transportu, magazynowania czy też stosowania wynikają głównie z jego palności, dużej gęstości ciekłego LNG w jego temperaturze wrzenia przy ciśnieniu atmosferycznym.

W zależności od ekspozycji cieplnej, strat ciepła do otoczenia w warunkach pożarowych, rodzaju emisji, czasu do zapłonu i typu efektywnego bodźca zapłonu - możliwy jest pożar lub wybuch mieszaniny palnej utworzonej z LNG.

Szybkość wycieków LNG, rozmiar rozlewisk, wilgotność powietrza, charakterystyka terenu (szczególnie zatłoczenie przeszkód), decydują o dyspersji chmury LNG i możliwych skutkach wybuchu.

Spalanie gazu ziemnego istotnie zależy od czasu przyłożeniem efektywnego źródła zapłonu i czasu utworzenia obłoku paliwo -powietrze.

W przypadku zapłonu par LNG możliwy jest pożar błyskawiczny chmury par z powietrzem, pożar strumieniowy, pożar rozlewiska lub wybuch mieszaniny par z powietrzem czy BLEVE. 


\section{$\star \star \star *$}

Literature analysis was carried out as part of the DOBBIO9/15/02/2018 project "Innovative research and training station LNG Trainer" implemented for the defence and security of the state used to develop tactics of activities with the use of equipment used by the State Fire Brigade (PSP) during LNG events, financed by the National Centre for Research and Development.

The experimental study was carried out as part of DOBBIO6/02/50/2014 project “Development of methods for neutralizing the risk of explosion in selected technical gas tanks, including alternative power sources in a fire environment for the needs of rescuers participating in rescue and firefighting operations" implemented for the defence and security of the state financed by the National Centre for Research and Development.

\section{Literature / Literatura}

[1] Kumar S., Kwon H., Choi K., Lim W., Cho J., Tak K., Moon I., LNG: an ecofriendly cryogenic fuel for sustainable development, „Applied Energy” 2011, 88, 4264-4273, https://doi. org/10.1016/j.apenergy.2011.06.035.

[2] U.S. Energy Information Agency, International Energy Outlook 2017.

[3] Mazyan W., Ahmadi A., Ahmed H., Hoorfar M., Market and technology assessment of natural gas processing: a review, „Journal of Natural Gas Science and Engineering" 2016, 30, 487-514, https://doi.org/10.1016/j.jngse.2016.02.010.

[4] Qi M., Park J., Kim J., Lee I., Moon I., Advanced integration of $L N G$ regasification power plant with liquid air energy storage: Enhancements in flexibility, safety, and power generation, „Applied Energy” 2020, 269, 115049, https://doi. org/10.1016/j.apenergy.2020.115049.

[5] https://app.mapfre.com/fundacion/html/revistas/seguridad/n127/en/article2.html [dostęp: 02.11. 2021].

[6] Abbasi T., Abbasi S.A., The boiling liquid expanding vapour explosion (BLEVE): mechanism, consequence assessment, management, "Journal of Hazardous Materials" 2007, 141(3), 489-519.

[7] Lisowski E., Czyżycki W., Transport and storage of LNG in container tanks, "Journal of KONES Powertrain and Transport" 2011, 18(3), 193-201.

[8] Lisowski E., Czyżycki W., Łazarczyk K., Simulation and experimental research of internal supports in mobile cryogenic tank, "Czasopismo Techniczne” 2010, 2-M, 8, 175-184.

[9] Łaciak M., Kiedy transport i magazynowanie gazu płynnego, paliw lotniczych, materiałów promieniotwórczych staje się bezpieczne? ADR 2011 w praktyce, materiały z XXVIII Seminarium Szkoleniowego, Tęgoborze 2011.

[10] Grzywa E., Molenda J., Technologia podstawowych syntez organicznych, WNT, Warszawa 2000.

[11] Bahadori A., Cryogenic Insulation Systems for LNG Industries, Thermal Insulation Handbook for the Oil, Gas, and

\section{$* \star *$}

Analizę literaturową wykonano w ramach projektu nr DOB-BI09/15/02/2018 realizowanego na rzecz obronności i bezpieczeństwa państwa pt. „Innowacyjne stanowisko badawczo-treningowe Trenażer LNG" służące do opracowania taktyki działań z wykorzystaniem sprzętu będącego na wyposażeniu PSP podczas zdarzeń LNG, finansowanego przez Narodowe Centrum Badań i Rozwoju.

Badanie eksperymentalne wykonano $\mathrm{w}$ ramach projektu nr DOB-BI06/02/50/2014 realizowanego na rzecz obronności i bezpieczeństwa państwa pt. „Opracowanie metod neutralizacji zagrożenia wybuchu wytypowanych zbiorników z gazami technicznymi, w tym alternatywnymi źródłami zasilania w środowisku pożarowym na potrzeby ratowników biorących udział w akcjach ratowniczo-gaśniczych" finansowanego przez Narodowe Centrum Badań i Rozwoju.

Petrochemical Industries, Gulf Professional Publishing, 303-321, 2014.

[12] Mokhatab S., Mak J., Valappil J., Wood D., Handbook of Liquefied Natural Gas, Gulf Professional Publishing 2013.

[13] Yue F., Wenliang L., Shujun C., Zeyuan W., Yongqiang L., Experimental and simulation study on the capacitive liquid level gauge of LNG vehicular cylinder, "Measurement" 164 (2020), 107930, https://doi.org/10.1016/j. measurement.2020.107930.

[14] Koopman R.P., Ermak D.L., Lessons learned from LNG safety research, „Journal of Hazardous Materials", 140(3), 412-428, https://doi:10.1016/j.jhazmat.2006.10.042.

[15] Koopman R.P., Baker J., Cederwall R.T., Goldwire H.C., Hogan W.J., Kamppinen L.M., Kiefer R.D., McClure J.W., McRae T.G., Morgan D.L., Morris L.K., LLNL/NWC 1980 LNG Spill Tests, Burro Series Data Report, vol. 1., Lawrence Livermore Laboratory 1982.

[16] Planas-Cuchi E., Gasull N., Ventosa A., Casal J., Explosion of a road tanker containing liquefied natural gas, „Journal of Loss Prevention in Process Industries" 2004, 17 (4), 315-321, https://doi.org/10.1016/j.jp.2004.05.005.

[17] Cormier B.R., Qi R., Yun G.-W., Zhang Y., Mannan M.S., Application of computational fluid dynamics for $L N G$ vapor dispersion modeling: A study of key parameters. dissertation, „Journal of Loss Prevention in Process Industries" 2008, 22(3), 332-352, https://doi.org/ DOI:10.1016/j.jlp.2008.12.004.

[18] Checkel M.D., Ting D.S. K., Bushe W.K., Flammability limits and burning velocities of ammonia/nitric oxide mixtures, "Journal of Loss Prevention in Process Industries" 1995, 8(4), 215-220, https://doi.org/10.1016/0950-4230(95)00027-X.

[19] Chen J.R., Tsai H.Y., Chien J.H., Pan H.J., Flow and flame visualization near the upper flammability limits of methane/ air and propane/air mixtures at elevated pressures, „Journal of Loss Prevention in Process Industries" 2011, 24950, 662-670, https://doi.org/10.1016/j.jlp.2011.05.012. 
[20] Claessen G., Vliegen, J., Joosten G., Geersen T., Flammability characteristics of natural gases in air at elevated pressures and temperatures, Loss Prevention and Safety Promotion in the Process Industries: Proceedings of the 5th International Symposium, Cannes, France, September 15-19, 1986.

[21] Gieras M., Klemens R., Rarata G., Wolanski P., Determination of explosion parameters of methane-air mixtures in the chamber of $40 \mathrm{dm}^{3}$ at normal and elevated temperature, "Journal of Loss Prevention in Process Industries" 2006, 19(2), 263-270, https://doi.org/10.1016/j.jp.2005.05.004.

[22] Vanderstraeten B., Tuerlinckx D., Berghmans J., Vliegen S., Van't Oost E., Smit B., Experimental study of the pressure and temperature dependence on the upper flammability limit of methane/air mixtures, "Journal of Hazardous Materials" 1997, 56(3), 237-246, https://doi.org/10.1016/ S0304-3894(97)00045-9.

[23] Feldbauer G., Heigl J., McQueen W., Whipp R., May W., Spills of $L N G$ on water: Vaporization and downwind drift of combustible mixtures, ESSO Research and Engineering Company Report No. EE61D-72 (Performed for the American Petroleum Inst.), 1972.

[24] Puttock J.S., Blackmore D.R., Colenbrander G.W, Field experiments on dense gas dispersion, „Journal of Hazardous Materials" 1982, 6(1-2), 13-41, https://doi. org/10.1016/0304-3894(82)80033-2.

[25] Koopman R.P., Baker J., Cederwall R.T., Goldwire H.C., Hogan W.J., Kamppinen L.M., Kiefer R.D., McClure J.W., McRae T.G., Morgan D.L., LLNL/NWC 1980 LNG spill tests, Burro Series Data Report, vol. 2, Lawrence Livermore Laboratory 1982.

[26] Rigas F., Sklavounos S., Simulation of Coyote series trials-Part II: A computational approach to ignition and combustion of flammable vapor clouds, "Chemical Engineering Science" 2006, 61(5), 1444-1452, https://doi. org/10.1016/j.ces.2005.09.005.

[27] Brown T., Cederwall R., Chan S., Ermak D., Koopman R., Lamson K., McClure J., Morris L., Falcon series data report: 1987 LNG vapor barrier verification field trials, Lawrence Livermore National Lab, CA (USA) 1990.

[28] Biao S., Wong J., Wadnerkar D., Utikar R.P.,. Pareek V.K., Guob K., Multiphase simulation of LNG vapour dispersion with effect of fog formation, „Applied Thermal Engineering" 2020, 166, 114671, https://doi.org/10.1016/j. applthermaleng.2019.114671.

[29] Eberwein R., Rogge A., Behrendt F., Knaust C., Dispersion modeling of LNG-Vapor on land - A CFD-Model evaluation study, "Journal of Loss Prevention in the Process Industries" 2020, 65, 104116, https://doi.org/10.1016/j.jp.2020.104116.

[30] Aneziris O., Papazoglou I.A., Konstantinidou M., Nivolianitou Z., Integrated risk assessment for LNG terminals, "Journal of Loss Prevention in the Process Industries" 2014, 28, 23-35, https://doi.org/10.1016/j.jp.2013.07.014.

[31] Pio G., Salzano E., The effect of ultra-low temperature on the flammability limits of a methane/air/diluent mixtures, „Journal of Hazardous Materials" 2019, 362, 224-229, https:// doi.org/10.1016/j.jhazmat.2018.09.018.
[32] Pio G., Carboni M., lannaccone T., Cozzani, V., Salzano E., Numerical simulation of small-scale pool fires of $L N G$, "Journal of Loss Prevention in the Process Indnustries" 2019, 61, 82-88. https://doi.org/10.1016/j.jlp.2019.06.002.

[33] Bartknecht W., Explosionsschutz, Grundlagen und Anwendung, Springer Verlag, Berlin, Heidelberg, New York 1993.

[34] Bunev V., Bolshova T., Babkin V., The nature of the upper laminar flammability limit in methane-air mixtures at high pressures, „Doklady Physical Chemistry” 2013, 452, 52-54, https://doi.org/10.1134/S001250161307004X.

[35] Basshuysen R., Erdgas und erneuerbares Methan für den Fahrzeugantrieb, Springer Verlag, Wiesbaden 2015.

[36] Lee S., Quantitative risk assessment of fire \& explosion for regasification process of an LNG-FSRU, "Ocean Engineering" 2020, 197(86), 106825, https://doi.org/10.1016/j. oceaneng.2019.106825.

[37] Dyrektywa Parlamentu Europejskiego i Rady 2012/18/UE z dnia 4 lipca 2012 r. w sprawie kontroli zagrożeń poważnymi awariami związanymi z substancjami niebezpiecznymi, zmieniająca, a następnie uchylająca dyrektywę Rady 96/82/WE [Dyrektywa Seveso III] (Dz. Urz. UE L 197 z 24.07.2012), 1-37.

[38] PN-EN 1473:2021-10 Instalacje i wyposażenie do skroplonego gazu ziemnego - Projektowanie instalacji na lądzie.

[39] PN-EN 13645:2008 Instalacje i urządzenia do skroplonego gazu ziemnego - Projektowanie instalacji lądowych ze zbiornikami magazynowymi o ładowności od $5 \mathrm{t}$ do $200 \mathrm{t}$.

[40] NFPA 59A Standard for the Production, Storage, and Handling of Liquefied Natural Gas LNG.

[41] Umowa europejska dotycząca międzynarodowego przewozu drogowego towarów niebezpiecznych - ADR 2021, https://dziennikustaw.gov.pl/DU/2021/874.

[42] PN-EN ISO 20421-2:2017-05 Zbiorniki kriogeniczne - Duże zbiorniki transportowe z izolacją próżniową - Część 2 : Wymagania eksploatacyjne.

[43] PN-EN 13530-2:2003 Zbiorniki kriogeniczne - Duże zbiorniki przenośne izolowane próżnią - Część 2: Projektowanie, wyrób, kontrola i badania. 
SENIOR BRIG. MARZENA PÓŁKA, PH.D., SGSP PROFESSOR - a graduate from the Faculty of Chemistry at the University of Warsaw. Professor and a long-term State Fire Service officer. She is a manager of the Combustion Processes Department at the Safety Engineering and Civil Protection Faculty of the Main School of the Fire Service in Warsaw. In her academic work, she focuses on thermal decomposition, material combustion, fire resistance modifications, description of flammable liquid vapours, gas and dust explosions, as well as, fire and explosion investigations.

DARIUSZ OLCEN, M.SC. ENG.- a graduate of engineering studies at the Main School of Fire Service (2007), a graduate of post-graduate studies in the field of Chemical Rescue - Identification of hazards and liquidation of contamination at the Main School of Fire Service and post-graduate studies in the field of Chemical Rescue at the Nicolaus Copernicus University in Torun (2018). Advisor for the transport of dangerous goods by road (DGSA). Author and co-author of the current training programs of the Headquarters of the State Fire Service in chemical and ecological rescue as well as CBRN.

BRIG. ROBERT PIEC, PH.D. ENG.- a graduate of the Main School of Fire Service. Doctor of technical sciences in the discipline of environmental engineering, awarded by the resolution of the Scientific Council of the Central Institute for Labour Protection - National Research Institute. He also completed postgraduate studies - Management in the States of Hazards at the Main School of Fire Service, postgraduate studies - Databases at the University of Information Technology and Management, and postgraduate studies with doctoral seminars - Risk analysis at the Academy of Finance. He is the author or co-author of many articles, chapters of monographs and papers presented at national and international conferences. Currently, he is the Director of the Institute of Internal Security of the Main School of Fire Service.
ST. BRYG. DR HAB. MARZENA PÓtKA, PROF. SGSP - absolwentka Wydziału Chemii na Uniwersytecie Warszawskim. Długoletni funkcjonariusz PSP pełniący obecnie służbę na stanowisku profesora nadzwyczajnego. Obecnie kierownik Katedry Procesów Spalania na Wydziale Inżynierii Bezpieczeństwa i Ochrony Ludności Szkoły Głównej Służby Pożarniczej. Zajmuje się analizą procesów rozkładu termicznego i spalania materiałów, modyfikacją przeciwogniową materiałów, opisem zjawisk wybuchu par cieczy palnych, gazów oraz pyłów, rozpoznawaniem przyczyny powstawania pożarów i wybuchów.

MGR INŻ. DARIUSZ OLCEN - absolwent studiów inżynierskich Szkoły Głównej Służby Pożarniczej (2007), absolwent studiów podyplomowych w zakresie Ratownictwa Chemicznego - Identyfikacja zagrożeń i likwidacja skażeń w SGSP oraz studiów podyplomowych w zakresie Ratownictwa Chemicznego na Uniwersytecie Mikołaja Kopernika w Toruniu (2018). Doradca ds. transportu drogowego towarów niebezpiecznych (DGSA). Autor i współautor obowiązujących programów szkoleń KG PSP z ratownictwa chemicznego i ekologicznego oraz CBRN.

BRYG. DR INŻ. ROBERT PIEC - absolwent Szkoły Głównej Służby Pożarniczej. Doktor nauk technicznych w dyscyplinie inżynieria środowiska nadany uchwałą Rady Naukowej Centralnego Instytutu Ochrony Pracy - Państwowego Instytutu Badawczego. Ukończył również studia podyplomowe - Zarządzenie w Stanach Zagrożeń w Szkole Głównej Służby Pożarniczej, studia podyplomowe - Bazy danych w Wyższej Szkole Informatyki Stosowanej i Zarządzania oraz studia podyplomowe z seminariami doktoranckimi - Analiza ryzyka w Akademii Finansów. Jest autorem lub współautorem wielu artykułów, rozdziałów monografii oraz referatów prezentowanych na konferencjach krajowych i zagranicznych. Obecnie pełni obowiązki Dyrektora Instytutu Bezpieczeństwa Wewnętrznego Szkoły Głównej Służby Pożarniczej. 